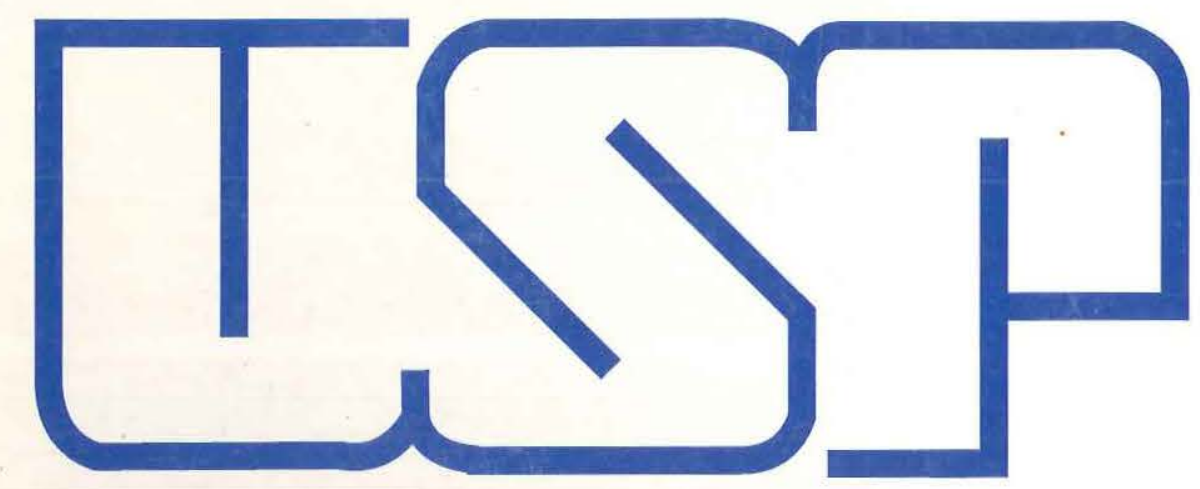

Ensaio Mecânico de Compressão Axial e

Flexão Em Três Pontos em Complexo Tibio-

Fibular de Ratos Adultos Jovens

Autor: Renato Alves Cazon

Orientador: Prof. Dr. José B. Volpon

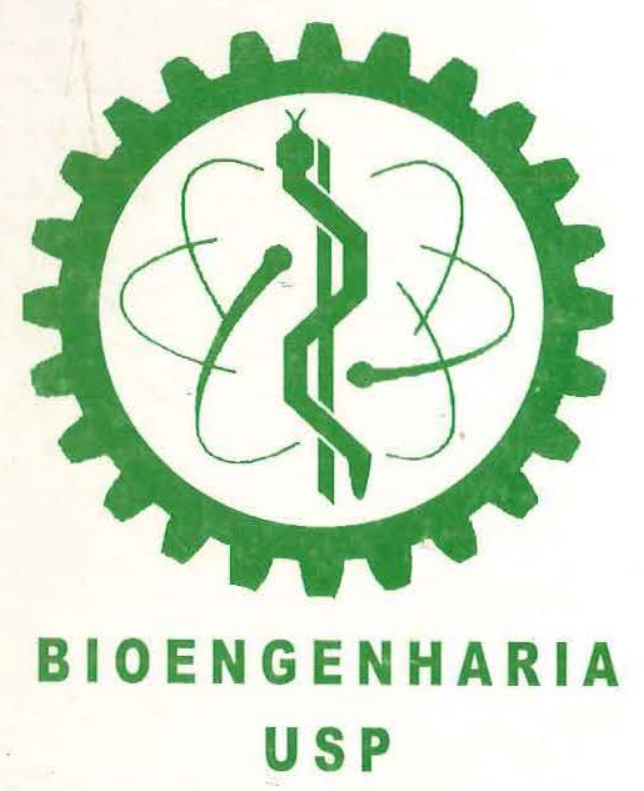

Curso de Pós-Graduação Interunidades Bioengenharia

Escola de Engenharia de São Carlos

Faculdade de Medicina de Ribeirão Preto

Instituto de Química de São Carlos 


\title{
ENSAIO MECÂNICO DE COMPRESSÃO AXIAL E FLEXÃO EM TRÊS PONTOS EM COMPLEXO TIBIO-FIBULAR DE RATOS ADULTOS JOVENS
}

\author{
RENATO ALVES CAZON
}

Dissertação apresentada à Escola de Engenharia de São Carlos / Faculdade de Medicina de Ribeirão Preto da Universidade de São Paulo / Instituto de Química de São Carlos, como parte dos requisitos para obtenção do título de Mestre em Bioengenharia / da Universidade de São Paulo.

ORIENTADOR: Prof. Dr. José B. Volpon

Ribeirão Preto

1999

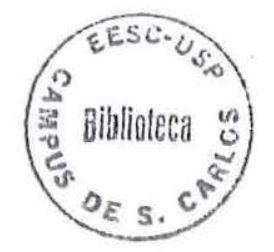


\begin{tabular}{|c|} 
Clase TESE-EEIC \\
$\frac{1446}{\text { Tombo To268 }}$ \\
St 1062439
\end{tabular}

Ficha catalográfica preparada pela Seção de Tratamento da Informação do Serviço de Biblioteca - EESC-USP

\section{Cazon, Renato Alves}

Ensaio de compressão axial e flexão em três pontos em complexo tibio-fibular de ratos adultos jovens / Renato Alves Cazon. - São Carlos, 1999.

Dissertação (Mestrado). - Área linterunidades em Bioengenharia da EESC/FMRP/IQSC - Universidade de São Paulo, 1999.

Orientador: Prof. Dr. José B. Volpon

1. Biomecânica. 2. Ensaio mecânico. 3. Tibio-fibular. 4. Rato. I. Título. 


\section{Universidade de São Paulo}

Curso de Pós-Graduação Interunidades Bioengenharia

Escola de Engenharia de São Carlos

Faculdade de Medicina de Ribeirão Prêto

Instituto de Química de São Carlos

Av. Dr. Carlos Botelho, 1465 - C.P. 359 - 13560-970 - São Carlos - SP - BRASIL

Tel. (016) 273-9585 Fax: (016) 273-9586

Email: bioeng@sc.usp.br

MEMBROS DA COMISSÃo JULGADORA DA DISSERTAÇÃO DE MESTRADO DO ALUNO RENATO ALVES CAZON APRESENTADA AO CURSO DE PÓSGRADUAÇÃO INTERUNIDADES BIOENGENHARIA EESC/FMRP/IQSC-USP, EM 30/07/1999.
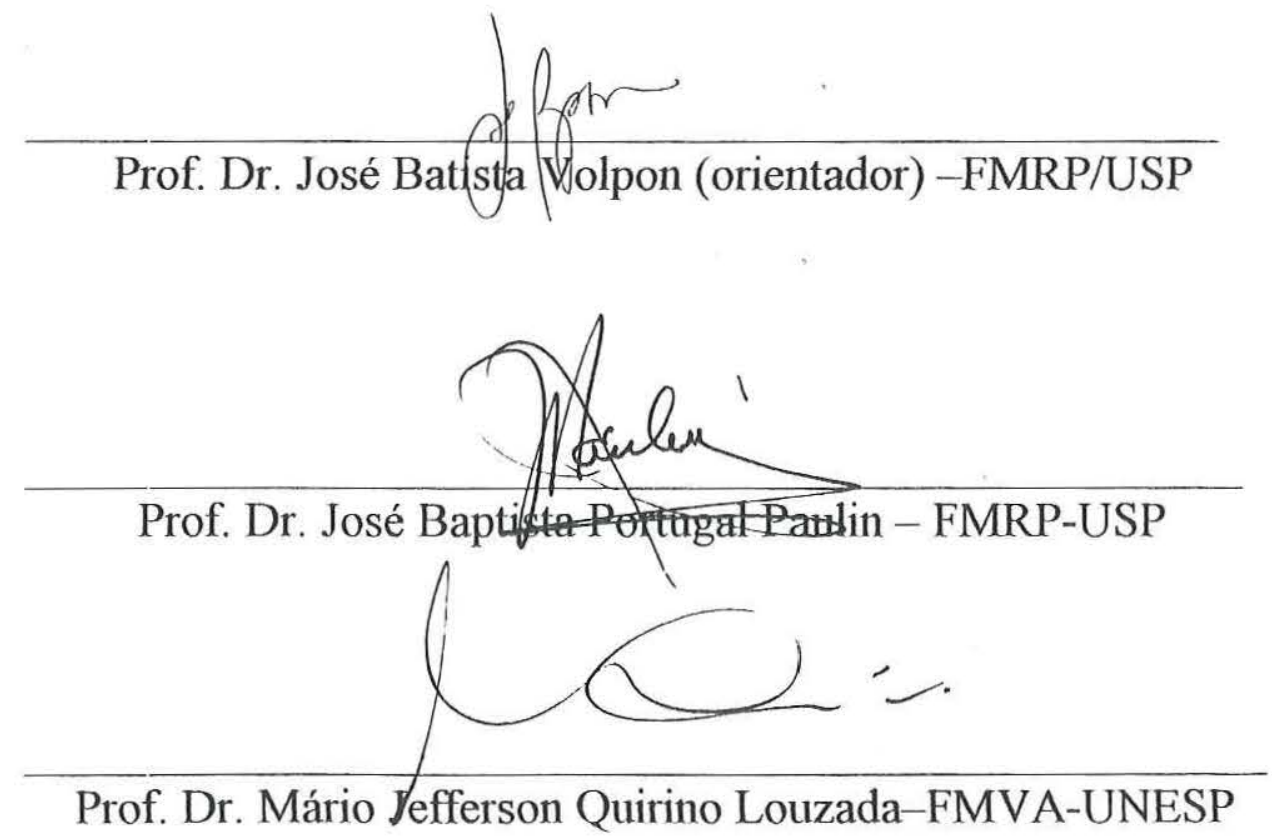
Aos meus queridos pais, José Morilo e Elvira, e à minha amada esposa Luciana, minha melhor amiga e incentivadora. 


\section{Agradecimentos}

Ao Prof. Dr. José B. Volpon, pela inspiração, respeito e compromisso com a orientação deste estudo.

Ao Prof. Dr. Antônio Carlos Shimano, pela paciência e ensinamentos.

Ao pós-graduando Adriano Holanda, pelo companheirismo e amizade sincera.

Aos pós-graduandos Marcos Shimano e Victor Castania, pelas idéias partilhadas no início desse estudo.

Aos funcionários Luiz Henrique Alves Pereira, Francisco Carlos Mazzocato, Carlos Alberto Moro, Maria Teresinha.de Moraes e Sônia Aparecida Rodrigues da Silva do Laboratório de Bioengenharia da Faculdade de Medicina de Ribeirão Preto da Universidade de São Paulo, pela amizade e disposição em servir.

À Marielza O. Roma e Janete F. Rodrigues, secretárias da Pós-graduação da EESC / USP, pela atenção e préstimos.

À Pós-graduação das Interunidades Bioengenharia EESC/FMRP/IQSC/USP, pela oportunidade de realização desse estudo.

A Deus, por tudo que Ele tem me permitido vivenciar. 
"É preferível a angústia da busca do que a paz da acomodação" 


\section{SUMÁRIO'}

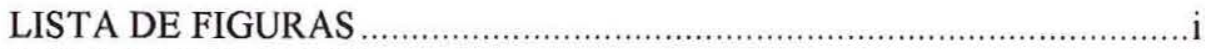

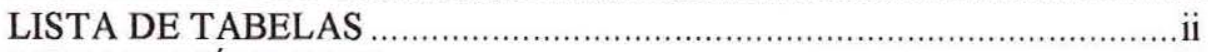

LISTA DE SÍMBOLOS ........................................................................

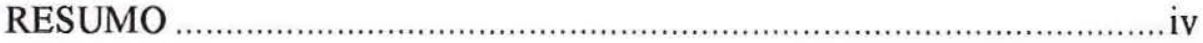

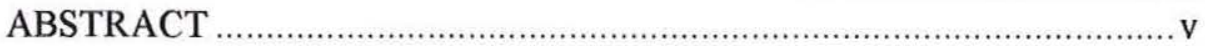

1 INTRODUÇÃO

2 OBJETIVO

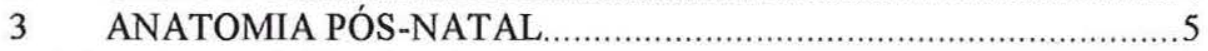

3.1 Anatomia Funcional e Comparativa ................................................ 8

3.2 Fatores mecânicos que levam à formação de cartilagem

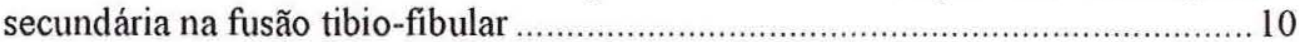

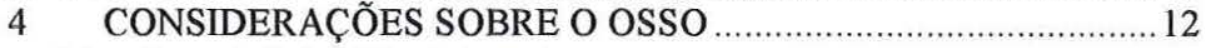

4.1 Propriedades Mecânicas dos ossos ............................................. 15

4.1.1 Biomecânica Básica.......................................................... 15

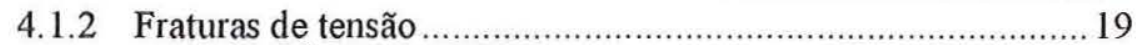

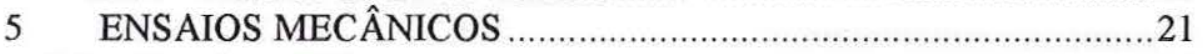

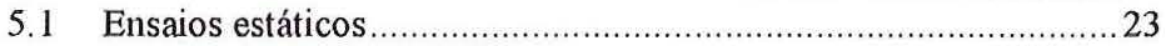

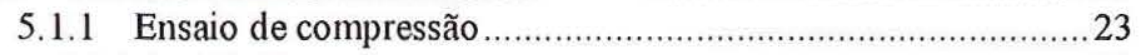

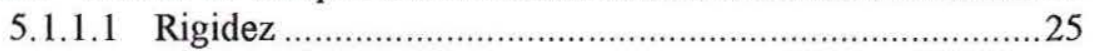

5.1.1.2 Limite máximo.....................................................26

5.1.1.3 Limite de proporcionalidade .........................................26

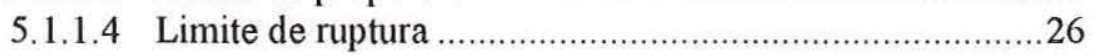

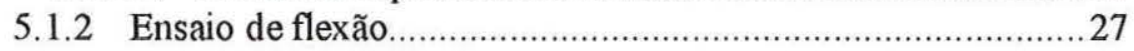

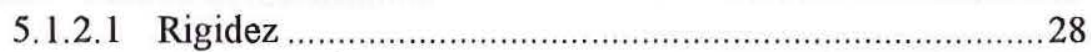

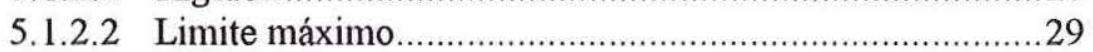

5.1.2.3 Limite de proporcionalidade ..........................................29

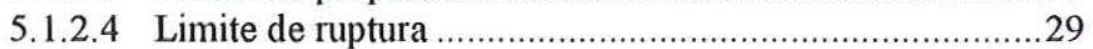

5.2 Ensaios Mecânicos do Osso ………................................................ 30

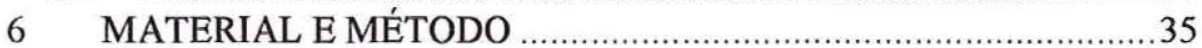

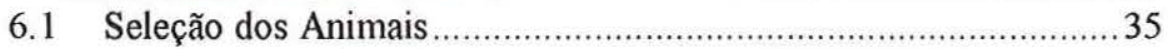

6.2 Ensaios Mecânicos de Compressão ................................................. 35

6.2.1 Preparo dos Modelos de Prova (das tíbias e fíbulas) ............... 35

6.2.2 Confeç̧ão do Suporte para Inclusão dos ossos em resina

acrílica

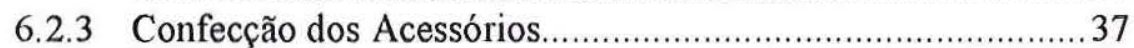

6.3 Realização do Ensaio Mecânico de Compressão ……………….... 37

6.4 Ensaios de Flexão em três Pontos .................................................. 39

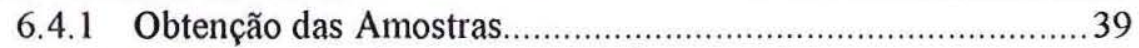

6.4.2 Confecção do Acessório Mecânico .........................................39

6.5 Realização do Ensaio Mecânico de Flexão em três Pontos ............ 40

6.6 Obtenção dos Parâmetros Mecânicos ............................................ 42

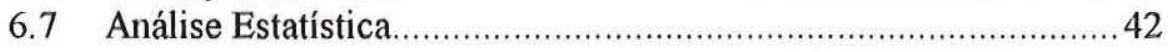

\footnotetext{
${ }^{1}$ Normas de acordo com as Diretrizes para Elaboração de Dissertações e Teses da EESC-USP 2 ' ed.
} 


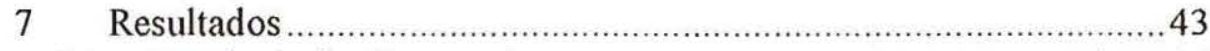

7.1 Ensaio de flexão em três pontos ............................................... 46

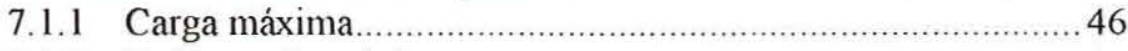

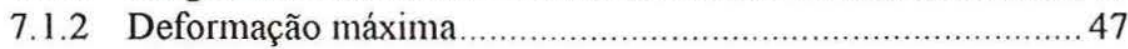

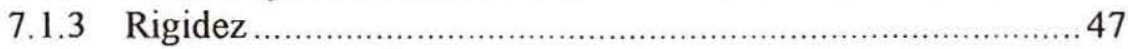

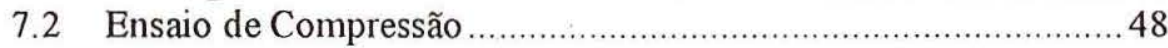

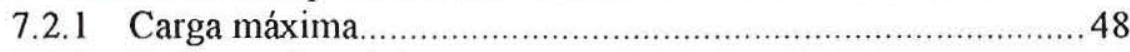

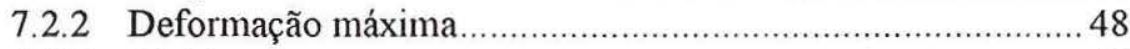

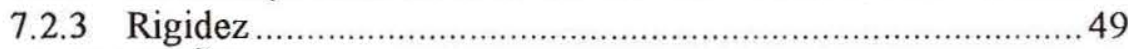

8 DISCUSS ÃO

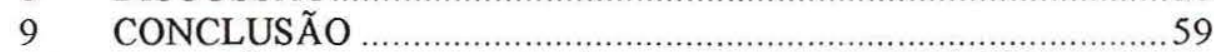

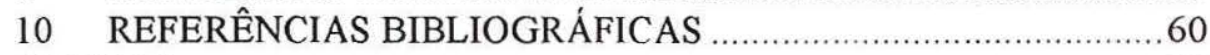

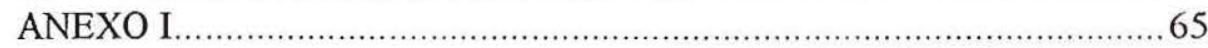




\section{LISTA DE FIGURAS}

FIGURA 1- Complexo tíbio-fibular do rato. (1) tíbia, (2) fibula, (3) fusão tibiofibular distalmente.

FIGURA 2 Representação esquemática dos três tipos básicos de tensão: tração, compressão e cisalhamento.

FIGURA 3. Representação esquemática da combinação de tensões durante a Flexão de um material: tensão de tração (lado convexo) e tensão de compressão (lado côncavo).

FIGURA 4. Representação esquemática das tensões que agem na diáfise do fêmur.

FIGURA 5. Representação esquemática da deformação provocada pela tensão de cisalhamento

FIGURA 6. Curva padrão carga x deformação

FIGURA 7. Representação esquemática mostrando o sentido de aplicação da carga no ensaio de compressão.

FIGURA 8. Diagrama carga $x$ deformação para o ensaio de compressão. ................ 25

FIGURA 9. Falha de material dútil e frágil sob compressão. ................................. 27

FIGURA 10. Configuração do carregamento no ensaio de flexão. .......................... 28

FIGURA 11. Curva carga $x$ deflexão do ensaio de flexão...................................... 28

FIGURA 12. Inclusão das unidades tíbio-fibulares em resina acrílica ...................... 36

FIGURA 13. Montagem do ensaio de compressão axial em unidades tíbio-

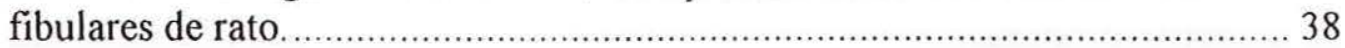

FIGURA 14. Acessório mecânico utilizado no ensaio de flexão em três pontos..... 39

FIGURA 15. Montagem do ensaio de Compresão em tíbia e fíbula de rato............. 41

FIGURA 16. Curva carga $x$ deformação das tíbias ensaiadas com fibula em compressão.

FIGURA 17. Curva carga $x$ deformação das tíbias ensaiadas sem fibula em * compressão.

FIGURA 18. Curva carga $x$ deformação das tíbias ensaiadas com fibula em flexão

FIGURA 19. Curva carga $x$ deflexão das tíbias ensaiadas sem fibula em flexão...... 45

FIGURA 20. Médias aritméticas das cargas máximas para as tíbias ensaiadas em flexão.

FIGURA 21. Médias aritméticas das deformações máximas para as tíbias ensaiadas em flexão.

Figura 22. Médias aritméticas das rigidez para as tíbias ensaiadas em flexão.......... 47

FIGURA 23. Médias aritméticas das cargas máximas para as tíbias ensaiadas em compressão.

FIGURA 24. Médias aritméticas das deformações máximas para as tíbias ensaiadas em compressão.

FIGURA 25. Médias aritméticas das rigidez para as tíbias ensaiadas em compressão. 


\section{LISTA DE TABELAS}

TABELA 1 Tabela das médias aritméticas e desvio padrão da carga máxima, deformação máxima e rigidez. 


\section{LISTA DE SÍMBOLOS}

$\sigma$ - tensão

$\varepsilon$ - deformação

F - força

A - área de secção transversal

$\Delta \mathrm{L}$ - variação de dimensão

$\mathrm{L}_{\mathrm{o}-\text { comprimento inicial }}$

$\mathrm{P}$ - carga axial $\mathrm{P}$

P'- carga axial P'

C - carga

d - deformação

$\mathrm{R}$ - rigidez

$\operatorname{tg} \theta$ - tangente do ângulo $\theta$

$\triangle \mathrm{C}$ - variação dos valores da carga

$\Delta \mathrm{d}$ - variação dos valores da deformação

C F- sentido do carregamento no ensaio de flexão

Kgf - quilograma-força

$\gamma$ - tensão de cisalhamento

c - cisalhamento

$\mathrm{N}$ - Newton 


\section{RESUMO}

CAZON, R. A. (1999) Ensaio mecânico de compressão axial e flexão em três pontos em complexo tíbio-fibular de rato. Ribeirão Preto, 1999. Dissertação (Mestrado)- Escola de Engenharia de São Carlos / Faculdade de Medicina de Ribeirão Preto/Instituto de Química de São Carlos, Universidade de São Paulo.

Este estudo teve como objetivo investigar uma provável função mecânica da fibula no complexo tibio-fibular de ratos. Para tanto, os complexos tibio-fibulares de 20 ratos da raça Norvegicus Albinus, variedade Wistar, foram submetidos a esforços de compressão axial e flexão em três pontos. Os animais eram adultos jovens, todos machos com peso corporal médio de $350 \mathrm{~g}$.

Foram utilizados 20 pares de tíbias para cada ensaio, sendo que, de um dos lados de cada par, a fibula foi mantida e, do outro lado, removida.

Foi utilizado uma máquina universal de ensaio para a realização de ambos os ensaios mecânicos. Os valores foram obtidos na forma de carga versus deformação (ensaio de compressão), e carga versus deflexão (ensaio de flexão). Os seguintes parâmetros foram analisados: carga máxima, deformação máxima e rigidez.

Da análise dos resultados foi concluído que a fibula, no rato, não aumenta a resistência do complexo tibio-fibular. Assim, a presença da fibula parece estar mais relacionada com função de inserções musculares do que fortalecimento tibio-fibular. 


\begin{abstract}
CAZON, R. A. (1999). Mechanical testing in compression and three point flexion of the rat tibiofibular complex. Ribeirão Preto, 1999. ...p. Dissertação (Mestrado)- Escola de Engenharia de São Carlos / Faculdade de Medicina de Ribeirão Preto/Instituto de Química de São Carlos, Universidade de São Paulo.
\end{abstract}

This study was conducted to investigate the contribution of the fibula to the mechanical resistance of the tibiofibular complex in the rat (both bones are fused distally). Twenty adult wistar rats were used as donor animals of twenty paired tibias. For each pair of bones in one side the fibula was excited and in the other side it was maintained. In a test machine the mechanical tests were done in three flexion and axial compression. The results were plotted either in load $\mathrm{x}$ deformation or load $\mathrm{x}$ deflection graphs the following parameters were analysed: ultimate load, ultimate deformation and rigidity.

It was concluded that the fibula does not increase the mechanical strength of the tibiofibular complex, but it may play a role as an anchorage for the muscles that act on the foot. 


\section{INTRODUÇÃO}

A região abaixo do joelho dos quadrúpedes geralmente contém dois ossos: a tíbia e a fibula. Esses ossos estão dispostos um ao lado do outro e separados por um espaço interósseo (BARNETT \& NAPIER, 1953a, b). Entretanto, em muitos fósseis e em quadrúpedes recentes observou-se a fusão distal entre a tíbia e a fibula, conforme os relatos de BELLAIRS \& JENKIN apud MOSS $(1977)^{2}$, assim como a fusão entre outros ossos do esqueleto, como as fusões carpometacárpicas, tibiotársicas, tarsometatársicas, já bem conhecidas em aves.

FROBOSE apud MOSS (1977) $)^{3}$ relatou a freqüente fusão do rádio com a ulna e da tíbia com a fibula em anfibios, e GUIBÉ apud MOSS (1977) ${ }^{4}$, a fusão de ossos em répteis.

Ao examinar murídeos (ratos e camondongos ancestrais), WILSON apud MOSS (1977) $)^{5}$ observou que nesses animais a tíbia e a fibula também apresentavam fusão óssea distalmente, embora em Sciuromorph mais evoluído esses ossos podem ser livres (esquilos), fundidos distalmente (alguns castores) ou consideravelmente fundidos (camundongo e diversos mamíferos roedores norte-americanos do gênero Geomys), enquanto que nos Hystricomorphs sul-americanos, de acordo com WILSON, nunca são fundidos totalmente.

ROMER apud MOSS $(1977)^{6}$ fez referência à ausência completa de fusão tíbio-fibular entre roedores ancestrais, como na Paramydiae.

\footnotetext{
${ }^{2}$ BELLAIRS, A.D.A.; JENKIN, C.R. (1960): The skeleton of birds; in Marshall Biol. comp. Physiol. Birds 1: 241-300.

${ }^{3}$ FROBOSE, H. (1927): Der Aufbau der Skeletteile in den freien Gliedmassen der anuren Amphibien. Morph. Jb., 58:473-566.

${ }^{4}$ GUIBÉ, J. (1970): La réduction des membres; dans Grasse Traité de zoologie, vol.14/II, pp. 194-201.

${ }^{5}$ WILSON, R. W. (1949): Early tertiary rodents of North America. Contr. Paleont., Carnagic Inst. Publ. N N $^{584}$, pp. 67-164.

${ }^{5}$ ROMER, A. S. (1966): Vertebrate paleontology; $3^{\text {rd }}$ ed. (University of Chicago Press, Chicago).
} 
A ausência da fusão tíbio-fibular é encontrada apenas em carnívoros e primatas (BARNETT \& NAPIER, 1953,a), e mostra ser um desenvolvimento evolutivo de uma melhor adaptação estrutural (CARLETON, 1941).

MOSS, em 1977, procurou analisar funcionalmente a fusão entre a tíbia e a fibula do rato. Foi o primeiro autor a descrever a seqüência histológica desse processo de fusão dos eixos diafisários distais do rato. Ao analisar histologicamente o desenvolvimento pré e pós nascimento de ratos da raça Columbia-Sherman e camondongos mostrou que, nestes animais, o processo de fusão entre a fibula e a tíbia inicia-se após o nascimento com a formação de cartilagem secundária no sítio da fusão, a qual é, subseqüentemente, substituída por ossificação endocondral envolvendo particularmente a união entre dois ossos bem diferenciados, enquanto que, em outros animais, ocorrem fusões interósseas cujo início antecede o nascimento, envolvendo elementos embrionários e cartilaginosos. Em um estudo paralelo, MOSS, removeu os membros traseiros de rato e de camondongo e os implantou em cérebros de hospedeiros. Com isso, inibiu a fusão entre a tíbia e a fibula, porém, a inibição só ocorreu quando houve remoção apenas da musculatura superficial ( extrínseca ao sítio de fusão). Esse autor procurou demonstrar com isto, que a fusão tibio-fibular no rato é induzida extrinsecamente por fatores mecânicos associados ao crescimento e função do membro e, ao comparar dados paleontológicos com dados anatômicos recentes que reforçam a sugestão de que fatores mecânicos estariam potencialmente envolvidos na produção da fusão dos membros traseiros, concluiu que tais fusões enquadram-se dentro da hipótese de um modelo funcional e são secundárias, compensatórias e mecanicamente obrigatórias como resposta às necessidades funcionais relacionadas a tecidos não esqueléticos $\mathrm{e}$ órgãos.

MATHEW apud MOSS (1977)? , já havia proposto um contexto biomecânico para o processo da fusão tíbio-fibular.

Apesar de fortes indícios de que a fusão distal entre a fibula e tíbia de alguns animais seja desencadeada por fatores mecânicos e que esse fato aumenta o papel

\footnotetext{
${ }^{7}$ MATHEW, W. D. (1937): Paleocene faunas of the San Juan basin, New Mexico. Trans. Am. phil. Soc., 30: $1-510$
} 
mecânico da fibula na transmissão de forças não há, na literatura consultada, estudos destes aspectos. 


\section{OBJETIVO}

Este estudo teve como objetivo investigar a função mecânica da fíbula no complexo tibio-fibular de ratos adultos jovens, por meio de esforços mecânicos de compressão axial e flexão em três pontos. 


\section{ANATOMIA PÓS-NATAL}

A tíbia e a fibula do rato adulto encontram-se fundidas paralelamente na região do terço distal de suas diáfises. Os dois terços não fundidos da fibula adulta estão situados posteriormente à tibia e são relativamente delgados quando comparados com a tíbia. A metade distal da região fundida, apresenta um entalhe visível demarcando as duas porções do eixo comum. O maléolo lateral (fibular) é bem distinto, embora definidamente fundido com a epífise distal da tíbia. A cabeça da fibula articula-se com o planalto tibial posteriormente, conforme mostra a FIGURA 1.

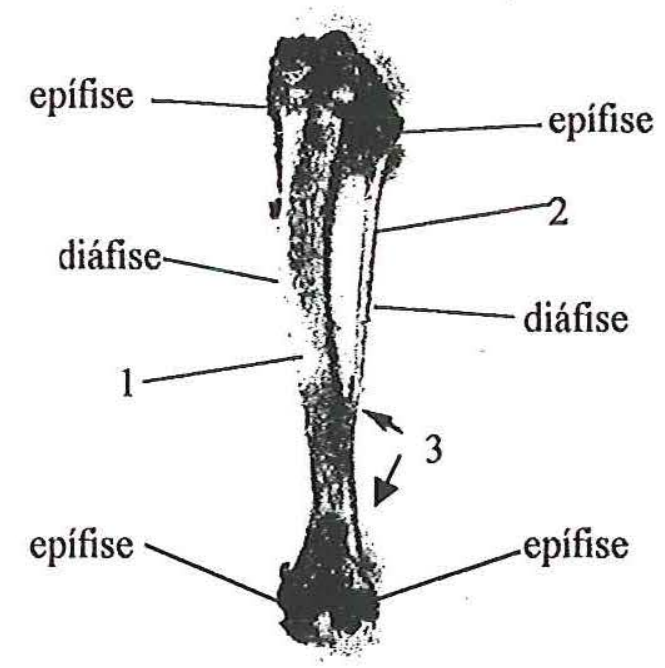

FIGURA 1- Complexo tíbio-fibular do rato. (1) tíbia, (2) fibula, (3) fusão tibio-fibular distalmente. 
Moss, em1977, analisou histologicamente a fusão entre tíbia e fibula de ratos da raça Columbia Sherman e camondongos e descreveu a sequência de eventos que ocorre nesse processo:

1. Ao nascimento, a tíbia e a fibula encontravam-se paralelas vistas anteroposteriormente, embora não estivessem paralelas no mesmo plano. A extremidade proximal da fibula estava inclinada posteriormente.

2. Por volta do quarto dia de vida o eixo da fibula arqueava-se medialmente atrás da diáfise da tibia, enquanto esta expandia-se em largura e cobria a fibula anteriormente.

3. Em torno do nono dia de vida, ocorria uma curvatura recíproca aproximando a diáfise distal das superfícies de ambos os ossos, vistas no plano transversal.

4. Ao nascimento, observava-se uma diferença evidente entre a região da futura fusão e a extremidade proximal, sítio não fundido. Anteriormente, eram encontrados dois revestimentos de periósteo. Suas camadas externas fibrosas eram delgadas, bem orientadas no sentido proximal para distal e continham fibroblastos dispostos similarmente.

5. O terço distal do espaço interósseo apresentava-se relativamente avascular possuindo grande número de células de tecido conjuntivo, discretamente alongadas no sentido proximal para distal. $\mathrm{O}$ quadro era de uma região com tendência a sofrer aplicação de cargas tensionais verticalmente.

6. Na maior parte da extremidade proximal, os tecidos conjuntivos interósseos possuíam melhor vascularização com número menor de células, também orientadas no mesmo sentido dos fibroblastos e do periósteo. Era observada uma diferenciação semelhante entre os espaços interósseos proximal e distal antes do nascimento. 
7. Após o nascimento, a cada dia, o espaço interósseo tornava-se acentuadamente constricto, juntamente com o arqueamento da fibula, havia crescimento lateral da tíbia e nivelamento mútuo de seus eixos distais extremamente unidos.

8. Os tecidos conjuntivos do espaço interósseo pareciam estar sob importante carga tensional vertical, de modo extremamente bem orientados no sentido proximal para distal. Não se observavam vasos neste tecido. A camada externa fibrosa dos tecidos periostais congruentes se tornavam duas ou três vezes mais densa do que era ao nascimento.

9. Por volta do sétimo dia ocorria a formação de cartilagem secundária que ocupava variavelmente o espaço interósseo distal. Entretanto, era possível, nesse estudo, identificar se esta cartilagem originava-se do periósteo ou de células do espaço interósseo. Não obstante, o terço distal do espaço interósseo rapidamente era preenchido por cartilagem secundária. Sinais evidentes de substituição endocondral dessa cartilagem eram encontrados nessa região.

10. A primeira evidência clara de ossificação era observada no décimo primeiro dia de vida do rato, embora evidências de formação óssea endocondral tenham sido verificadas em estágios anteriores a esse. Uma quantidade relativamente grande de cartilagem secundária era formada, enquanto a substituição óssea subseqüente ocorria de forma mais lenta, com diferenciação da cartilagem secundária durante as próximas duas ou três semanas. Finalmente, toda a cartilagem era substituída, pelo processo comum de remodelação óssea, as cavidades medulares de ambos os ossos tornavam-se interconectadas e os dois eixos diafisários fundidos tornavam-se um único tubo de osso periosteal. 


\subsection{Anatomia Funcional e Comparativa}

A fusão entre a tíbia e a fibula em mamíferos é apenas uma incidência específica desse evento que é comum em quadrúpedes, segundo FROBOSE apud MOSS (1977) ${ }^{8}$. Em mamíferos Eutheria, a forma da articulação tíbio-fibular e a ocorrência ou não de fusão entre esses ossos parece estar relacionada com o modo de locomoção da espécie (CARLETON, 1941; BARNETT \& NAPIER, 1953; WEINERT et al. 1973).

A fusão entre tíbia e fibula é bem marcada distalmente, e isso mostra que a articulação distal desta região é biomecanicamente importante (WALMSLEY apud MOSS, 1977). As numerosas modificações da relação tíbio-fibular estão relacionadas com modificações da articulação tíbio-társica (WALMSLEY apud MOSS, 1977; CARLETON,1941). Esses achados sugerem que a fusão da região distal tíbio-fibular esteja relacionada com um mecanismo de adaptação específico dessa região dos membros traseiros (MOSS, 1977).

Em pernas de répteis, a tíbia sempre foi mais robusta do que a fibula e é uma importante área de fixação muscular. Contudo, há uma tendência geral em répteis terrestres para a redução dessa largura e robustez, segundo ROMER apud MOSS (1977). ROMER apud MOSS (1977) ${ }^{10}$ relatou, ainda, que a tíbia e a fibula são bem separadas em certos crocodilos, embora em carnossauros os dois ossos estejam intimamente aproximados para aumentar seu comprimento, e estão em contato direto

distalmente. Funcionamente, esse autor correlacionou a fusão tíbio-fibular em roedores como o desenvolvimento para um tipo de locomoção em saltitamento.

Contínuas evidências de uma descarga biomecânica filogenética progressiva ou contínua sobre a fibula, proveniente da tarefa de suporte de peso é encontrada na

\footnotetext{
${ }^{8}$ FROBOSE, H. (1927): Der Aufbau der Skeletteile in den freien Gliedmassen der anuren Amphibien. Morph. Jb., 58:473-566.

${ }^{9}$ WALMSLEY, T. (1918). The reduction of the mammalian fibula. J. anat. v.52, p. $327-331$.

${ }^{10}$ ROMER, A. S. (1956): Osteology of reptiles (University of Chicago Press, Chicago).
} 
transição entre teraspides e mamíferos, associado com a superposição do tálus sobre o calcâneo, conforme os achados de SCHAEFFER apud MOSS (1977) ${ }^{11}$.

MATHEW apud MOSS (1977) ${ }^{12}$ distinguiu na fauna paleocênica, quatro tipos principais de morfologia de tálus, relacionando sua posição com a tíbia e a fibula. Quando o tálus é em forma de cunha e entre esses dois ossos, a fibula possui estrutura moderadamente robusta e ela não se funde. Entretanto, quando o tálus se encontra diretamente sob a tíbia, a fibula tende a co-ossificar-se com a tíbia, e a parte mais proximal da fibula tende a desaparecer. MATHEW propôs, então, um contexto biomecânico para o processo geral de fusão tíbio-fibular.

${ }^{11}$ SCHAEFFER, B. (1941): The Morfhological and Functional evolution of the tarsus in amphibians and reptiles. Bull. Am. Mus. nat. Hist. 78/6: 395-472.

${ }^{12}$ MATHEW, W. D. (1937): Paleocene faunas fo the San Juan basin, New Mexico. Trans. Am. phil. Soc., 30: 1-510. 


\subsection{Fatores mecânicos que levam à formação de cartilagem secundária na fusão tibio-fibular}

Dentre os muitos fatores biofísicos conhecidos que afetam tecidos esqueléticos descritos por BASSETT apud MOSS $(1977)^{13}$, está claro que forças mecânicas relacionadas ao movimento entre ossos adjacentes estão originariamente relacionadas à produção de cartilagem secundária (MOSS, 1958). É conhecido que o periósteo é capaz de produzir cartilagem sob certas circunstâncias como, por exemplo, reparação de fratura (ENNEKING, 1948).

Adicionalmente, forças mecânicas de origens extrínsecas específicas, foram implicadas no processo de condrogênese periosteal. Certos movimentos tangenciais de pequena extensão combinados com discreta pressão, experimentalmente, provocam o aparecimento de metaplasia cartilaginosa, conforme os achados de LERICHE \& POLICARD apud MOSS $(1977)^{14}$, diferentemente do fator extrínseco causal que induz à formação de membrana óssea de embriões de pintainho, que é pressão intermitente e tensão (HALL 1971, 1972,b)

KROMPECHER apud MOSS (1977) ${ }^{15}$, apontou a importância das cargas compressivas em condrogênese. O trabalho de GLUCKSMANN (1939) mostrou, em estudos in vitro, que muitos dos efeitos estruturais resultantes da tensão mecânica in vivo, são devidos à ação direta das tensões no próprio tecido esquelético.

Mais recentemente, HALL (1970, 1971, 1972a,b) estudou sistematicamente os eventos mecânicos relacionados com a formação inicial e destino subseqüente da cartilagem secundária, particularmente daquelas oriundas dos tecidos periosteais. Concordando que essas células periosteais têm uma natureza bipotencial capaz de produzir cartilagem ou osso, a direção desse tipo de diferenciação pode ser influenciada e orientada no sentido da condrogênese por forças mecânicas (HALL, 1970). A Imobilização de tais ossos causa a produção de cartilagem secundária (HALL, 1971, 1972a). Revisões mais completas de cartilagem secundária, comparando com a cartilagem primária, e os fatores causadores dessa diferenciação,

${ }^{13}$ BASSETT, C. A. L. (1971): Biophysical principles affecting bone structure; in Bourne The biochemistry and physiology of bone; $2^{\text {nd }}$ ed., vol 3; pp. 1-76 ( Academy Press, New York).

${ }^{14}$ LERICHE, R \& POLICARD, A (1928): The normal and pathological physiology of bone. Its problems (Mosby, St Louis).

${ }^{15}$ KROMPECHER, S. (1937): Die Knochenbildung (Fischer, Jena). 
foram estudados por DURKIN et al. (1971). A inibição de condrogênese pode ser produzida mecanicamente (HALL, 1972), principalmente por miotomia de músculos específicamente relacionados (HALL \& JACOBSON, 1975). Forças musculares associadas com a morfologia de superfícies articulares relacionadas produzem efeitos mecânicos no micromovimento entre esses dois ossos. Isto induz a formação de cartilagem secundária entre esses tecidos periostais congruentes, segundo MINDEL et al, 1971.

Baseado nos dados citados anteriormente, MOSS (1977) acreditou que a função dos membros antes e após o nascimento poderiam direcionar para a fusão interóssea via condrogênese somente quando as superfícies ósseas opostas exibissem ótima congruência. Esses pequenos espaços interósseos pareciam ser capazes de formação de cartilagem secundária somente quando eles não continham outros tecidos musculares ou rede vascular extensa, sugerido de maneira enfática, que não existem instruções genômicas codificadas intrinsecamente dentro dessas células periosteais, que invocarão tal fusão interóssea sem a aplicação de eventos biomecânicos extrinsecamente apropriados. 


\section{CONSIDERAÇÕES SOBRE O OSSO}

"O osso é um derivado do tecido conjuntivo original, porém constitui uma forma altamente especializada e é diferente do tecido conjuntivo propriamente dito pelo fato de ser muito duro. Consiste de osteócitos, que são células com processos longos e ramificados que ocupam cavidades denominadas lacunas numa densa matriz feita de fibras colágenas disseminadas numa substância primordial amorfa denominada cimento, que está impregnada com complexos de fosfato de cálcio. Os componentes celulares do osso estão associados com funções específicas. Os osteoblastos participam na formação do osso, os osteócitos são responsáveis pela manutenção do osso como tecido vivo e os osteoclastos participam na destruição e na reabsorção do osso. Muitos ossos, ou parte dos mesmos, são estruturas sólidas e compactas, nutridas através de canais que conduzem vasos sangüíneos e por meio de minúsculos túbulos que unem os espaços celulares entre si e com os demais canais. Os ossos longos são sólidos apenas na superficie, no seu interior são ocos, porém, um número suficiente de esteios (trabéculas) ósseos se estende do exterior ósseo sólido até dentro do interior oco, para reforçá-lo de maneira mais ou menos semelhante ao modelo de construção de muitas pontes. O espaço existente nos corpos dos ossos longos não é desperdiçado, sendo cheio com medula óssea" (ASTRAND \& RODAHL, 1980). "O osso representa o arcabouço do aparelho locomotor que, além de ser um elemento importante no metabolismo de sais minerais, na albergagem de tecido hemopoiético e nervoso, desempenha funções mecânicas de sustentação do peso corporal e ainda fornece alavancas para realização de movimentos, por meio dos tendões e músculos nele inseridos . Por definição, osso longo é aquele que tem o comprimento muitas vezes maior que a largura. Todos os osso longos têm uma estrutura básica comum. Há um corpo cilíndrico central chamado diáfise que apresenta no interior o canal medular, preenchido por medula óssea, que no adulto é pouco ativa no sentido de formar células sanguíneas, servindo de depósito gorduroso. A parede da diáfise chama-se córtex que é formado por osso bastante denso e resistente - osso lamelar ou cortical. À medida que se avança para as extremidades, a diáfise vai alargando-se e a córtex vai adelgando-se dando origem à metáfise. Nesta região não há mais canal medular, pois todo o osso está preenchido por lamelas 
ósseas que espacialmente assumem orientações variadas, formando o osso esponjoso" (VOLPON, 1994).

"As extremidades do osso longo chamam-se epífises cujas superficies são revestidas pela cartilagem articular. Nas crianças a epífise é formada pelo núcleo de ossificação secundário e pela cartilagem de crescimento que é estrutura bastante delicada, e responsável pelo crescimento longitudinal do osso. Externamente, o osso longo é revestido por uma membrana chamada periósteo que tem, em sua parte mais profunda, células osteogênicas que, por um mecânismo aposicional, promovem o crescimento ósseo em espessura. O periósteo, na região epifisária, continua-se com uma estrutura equivalente que é o pericôndrio que, por sua vez, tem íntimo relacionamento com a periferia da cartilagem de crescimento. Internamente, revestindo o canal medular, há uma membrana semelhante ao periósteo, chamado endósteo, também capaz de produzir ou absorver osso. Normalmente, há equilíbrio entre as atividades do periósteo e endósteo de tal maneira que, à medida que tecido ósseo é depositado na superficie externa, há reabsorção correspondente na superficie interna, de maneira a manter a córtex e o canal medular com dimensões definidas e proporcionais. Este mecanismo é muito importante para a remodelação óssea. Em algumas situações patológicas o equilibrio pode ser rompido formando-se ossos maciços ou então excessivamente ocos. Em ambas as situações tornam-se frágeis e quebram-se facilmente" (VOLPON, 1994).

"O osso como um elemento vivo necessita de aporte sanguíneo e a irrigação deve estar compatibilizada com sua estrutura. Basicamente há vasos epifisários, metafisários e diafisários. A menor unidade macroscópica do osso é a lamela óssea. No osso compacto elas estão justapostas, com orientação comum e deixando espaço entre si. No osso esponjoso essa lâminas têm orientação, formando espaços ou lacunas que, são preenchidas por medula óssea Entretanto, em uma radiografia ou corte do osso esponjoso, verifica-se facilmente que há grupos de lamelas que têm orientação comum formando feixes que representam sistemas de reforço da estrutura e refletem regiões de descargas de forças" (VOLPON, 1994).

Um dos fatores responsáveis pela manutenção do metabolismo mineral normal dos ossos é a pressão longitudinal exercida sobre eles, produzida pela tensão da gravidade sobre o arcabouço humano (RODAHL et al. apud ASTRAND \& 
RODAHL 1980) ${ }^{16}$. A pressão estimula o crescimento ósseo por aposição. A descarga de peso resultará em maior espessura do osso e maior densidade da diáfise (ASTRAND \& RODAHL, 1980).

Estudos do efeito do repouso prolongado no leito sobre o metabolismo do cálcio ( RODAHL et al. apud ASTRAND \& RODAHL, 1980) ${ }^{17}$ mostraram que o aumento na excreção urinária de cálcio, que ocorre durante um confinamento prolongado ao leito, não é devido à inatividade mas sim à ausência de pressão longitudinal sobre os ossos longos. Se a excreção urinária de cálcio pode ser entendida como uma indicação da desmineralização óssea, parece que a tensão gravitacional sobre os ossos longos é essencial para o crescimento ósseo normal. Isto foi consubstanciado por WHEDON et al. apud ASTRAND \& RODAHL (1980) ${ }^{18}$, após estudos sobre metabolismo do cálcio em astronautas durante os longos vôos espaciais. Assim sendo, é evidente que o aparecimento de maior rigidez e resistência do osso é gerado ao submetê-lo a um aumento de pressão (ASTRAND \& RODAHL, 1980).

Todos os elementos do esqueleto interno são formados primeiro da cartilagem no embrião humano. Posteriormente, a cartilagem é substituída por osso. As trabéculas ósseas que não recebem tensão desaparecerão e surgirão novas trabéculas onde forças mecânicas alteradas exigem uma maior rigidez. Assim sendo, em conseqüência do treinamento ou de uma fratura as linhas de força num osso podem mudar com a alteração da direção das forças mecânicas (ASTRAND \& RODAHL, 1980).

\footnotetext{
${ }^{16}$ RODAHL, K.N.C; BIRKHEAD.; BLIZZARD, J.J.; ISSEKUTZ, B.Jr.; PRUETT, E.D.R. (1966). Fysiologiske forandringer under langvarig sengeleie, Nord. Med., v. 75, p. 182.

${ }^{17}$ RODAHL, K,J,T. NICHOLSON, and E. M. BROWN (eds.): Bone as a Tissue,"McGraw-Hill Book Company, New York, 1960.

${ }^{18}$ WHEDON, G.D.; LUTWAK, L.; RAMBAUT, P.; WHITTLE, M.; LEACH, C. REID, J.; SMITH, M. (1975). Mineral and Nitrogen Metabolic Studies on Skylab Flights and Comparison with Effects of Earth Long-Term Recumbency, Proc. COSPAR Symposium on Gravitational Physiology, Varna, Bulgaria, Bulgarian Academy of Sicences Press, Sofia, May 30-31.
} 


\subsection{Propriedades Mecânicas dos ossos}

Osso é um tecido vivo e dinamicamente adaptável que se remodela continuamente. $\mathrm{O}$ entendimento dessa característica é fundamental para a compreensão de suas propriedades mecânicas (GOULD, 1993). Com as observações de GALILEO, foi assumido que a arquitetura inerente do osso é influenciada pelas tensões mecânicas associadas à sua função normal. Mais tarde, uma definição mais formal dessas relações entre estrutura e função foram estabelecidas por WOLFF, em 1892. Os princípios da lei de WOLFF estão baseados no conceito que há uma correlação entre os padrões de alinhamento trabecular e as direções das tensões principais causadas pela função normal do osso. Como qualquer estrutura, as propriedades mecânicas deste tecido refletem as propriedades materiais inerentes de seus componentes e a maneira que eles estão organizados e interagem. Porém, o osso se distingue pela sua característica anisotrópica e viscoelástica. Estas características, juntamente com a habilidade do osso de se adaptar continuamente às exigências funcionais de seu ambiente mecânico, torna dificil estabelecer constantes universais para caracterizar suas propriedades físicas (EINHORN, 1996). Para avaliar a integridade mecânica de osso, é preciso que se conheçam os fatores específicos que contribuem para suas propriedades.

\subsubsection{Biomecânica Básica}

O osso, como todos os materiais na natureza, sofre deformação quando é submetido à aplicação de uma força. Se o osso é comprimido de forma que não possa se mover, ou se sobre ele são aplicadas forças iguais e opostas, a deformação acontecerá e resultará na geração de uma reação interna à força aplicada. Esta reação interna é conhecida como tensão. Tensão é distribuída sobre a área de seç̧ão transversal do osso. É expressa em unidades de força por unidade de área:

$$
\text { tensão }=\sigma=\frac{\text { força }}{\text { área }}
$$

A unidade internacional para tensão é o Pascal que é a força de $1 \mathrm{~N}$ distribuída sobre $1 \mathrm{~m}^{2}$. 
Embora uma força aplicada externamente possa atuar em um espécime em vários ângulos, produzindo padrões de tensão complexos no material, todas as tensões podem ser agrupadas em três tipos: tração, compressão, e cisalhamento (EINHORN, 1996).

\section{TRAÇÃO COMPRESSÃo CISALHAMENTO}
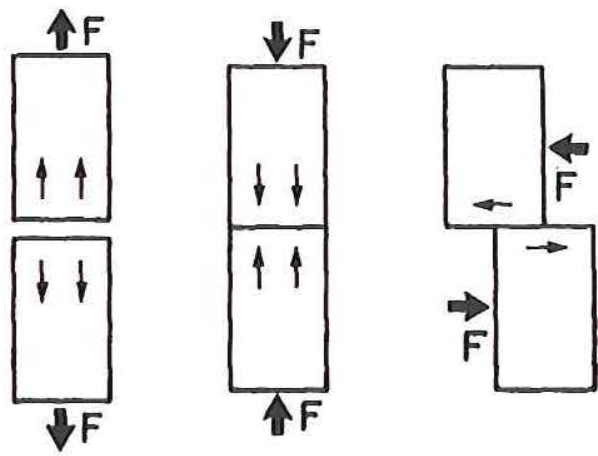

FIGURA 2 Representação esquemática dos três tipos básicos de carregamento: tração, compressão e cisalhamento. (Fonte: EINHORN, 1996)

É produzida tração em um material quando duas forças com sentidos opostos e mesma direção tracionam as extremidades do material (alongando-o). Compressão é o resultado de duas forças que agem na mesma direção e em sentidos opostos (vão de encontro uma à outra). Cisalhamento é produzido quando são dirigidas duas forças paralelas entre si com mesma direção e sentidos opostos, não pertencentes à mesma linha de aplicação de esforço. A resistência máxima à essa tração, à compressão ou cisalhamento pode ser medida (EINHORN, 1996).

A maioria da tensões são combinações complexas destes três tipos de solicitação. Por exemplo, a flexão é uma combinação de tensões de tração no lado convexo de um material e forças compressivas no lado côncavo (FIGURA 3). Torção, é a combinação de tensões de cisalhamento, tração e compressão. A medida da deformação $\varepsilon$ é normatizada para o comprimento inicial de um corpo de prova, sendo obtida pelo seguinte cálculo:

$$
\varepsilon=\frac{\text { comprimento_final }- \text { comprimento_inicial }}{\text { comprimento_inicial }}
$$




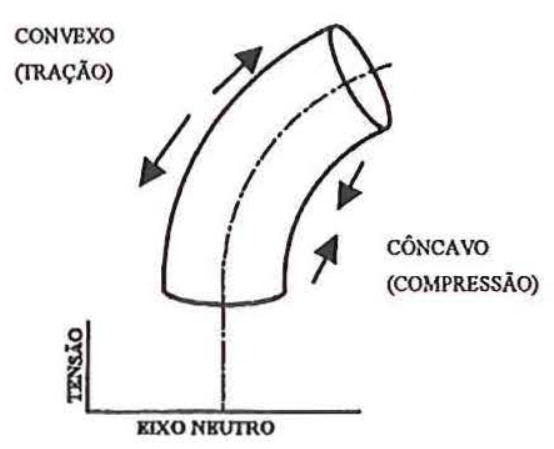

FIGURA 3. Representação esquemática da combinação de tensões durante a flexão de um material: tração (lado convexo) e compressão (lado côncavo). (Fonte: EINHORN, 1996)

A aplicação destas condições pode ser feita considerando as tensões $x$ deformações geradas na diáfise do fềmur (FIGURA 4).

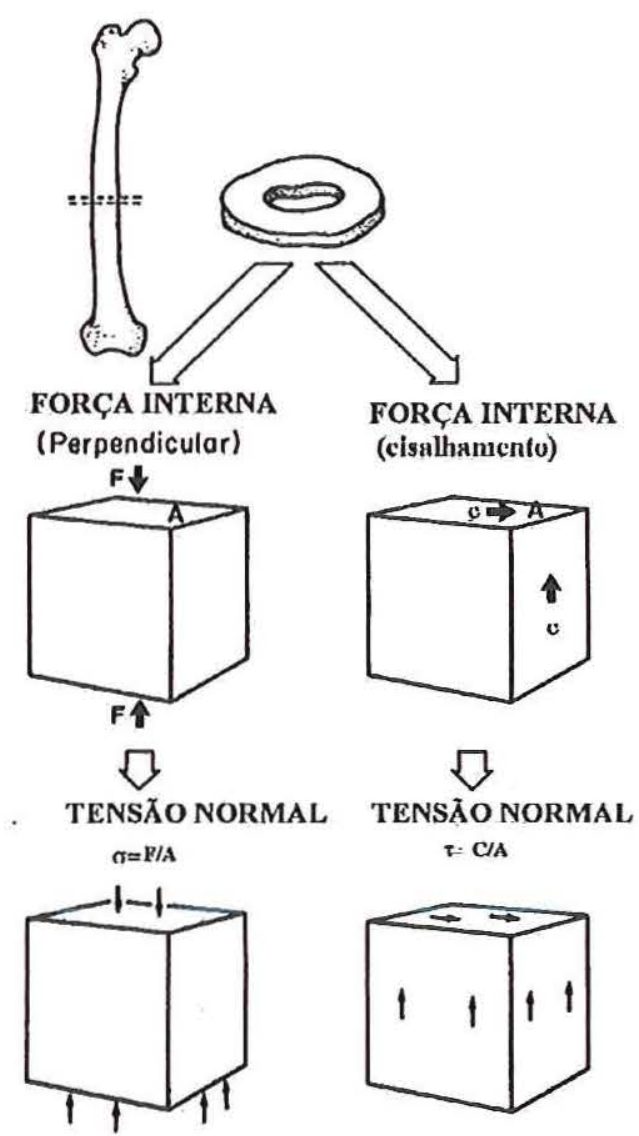

FIGURA 4. Representação esquemática das tensões que agem na diáfise do fềmur. (Fonte: EINHORN, 1996) 
Para isso, deve-se supor que uma seção transversal delgada do osso comporta-se como um cubo pequeno; a face superior do cubo será chamada de A. Dois tipos de força interna podem agir em A. Uma força perpendicular $F$ que produz uma tensão $\sigma$ normal, igual a $F / A$ e uma força de cisalhamento $c$, que resulta em uma tensão cisalhamento de $\tau$, igual a $C / A$. Uma tensão normal poderia ser aplicada à face do cubo, nesse caso chamada de compressão, ou longe da face do cubo nesse caso é chamado de tração (EINHORN, 1996).

As tensões descritas causam deformação local do cubo (FIGURA 5). Uma tensão compressiva normal causará no cubo uma diminuição do comprimento $L$, e é definida como a mudança em comprimento do lado do cubo $\Delta \mathrm{L}$ a partir do comprimento original $L(\epsilon=\Delta L / L)$. Uma tensão de cisalhamento aplicada à face superior do cubo causará deformação da face dianteira, e a tensão de cisalhamento resultante pode ser definida como a divergência de um lado do cubo de seu ângulo original, i.e., $\tilde{a}=\Delta L / L$ (EINHORN, 1996)

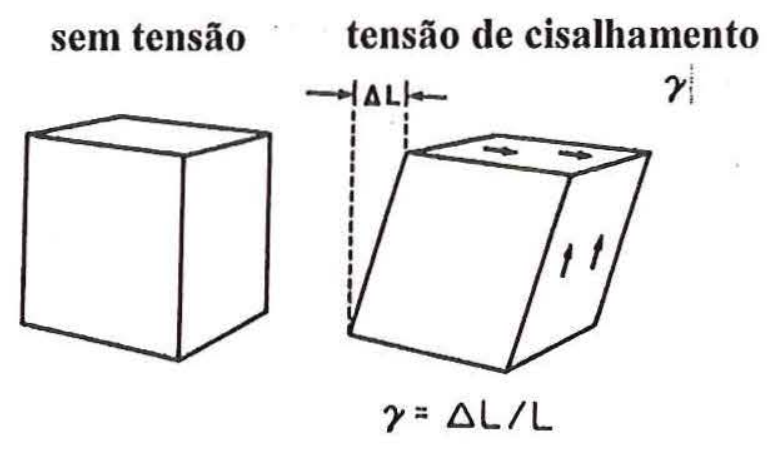

FIGURA 5. Representação esquemática da deformação provocada pela tensão de cisalhamento. (Fonte: EINHORN, 1996).

Considerando que o cubo representa uma secção de osso, as tensões normais e de cisalhamento experimentadas pelo tecido não só serão influenciadas pela magnitude das tensões aplicadas, mas também pelas propriedades materiais inerentes do osso. Forças normais aplicadas no tecido ósseo bem mineralizado causarão deformações pequenas. Entretanto, considerando as mesmas forças aplicadas no tecido ósseo desmineralizado, como observado em doenças osteomalaceas, 
produzirão deformações grandes. Disto tem que ser lembrada, porém, que tensões aplicadas ao osso, não possuem apenas direções perpendiculares e horizontais, mas, também, direções oblíquas, resultando em uma variedade de relações mecânicas complexas. Assim, além de magnitude e direção, o sentido de uma força deve ser conhecida para determinar as tensões exercidas sobre um determinado tecido (EINHORN, 1996).

\subsubsection{Fraturas de tensão}

Uma fratura representa uma ruptura do tecido ósseo do ponto de vista material (amostra) e do ponto de vista estrutural (osso inteiro) (HAYES \& CARTER apud EINHORN, 1996) ${ }^{19}$. Nem sempre é necessário que a tensão máxima seja excedida para que uma fratura aconteça. Repetidos carregamentos e descarregamentos do osso podem causar falha até mesmo com cargas pequenas. Este fenômeno é conhecido como fratura por fadiga. Falha por fadiga acontece quando de forma cíclica o carregamento produz uma quantidade pequena de microdanos acumulados com cargas repetitivas (SCHAFFLER et. al., 1994). Materiais biológicos (como o osso) possuem mecanismos para reparação desses microdanos. Em condições normais, acontecerão microdanos mas eles não possuem efeitos cumulativos, sendo reparados constantemente. Porém, quando os mecanismos de reparação normais são prejudicados ou se tornam menos eficientes (por exemplo, em certas doenças metabólicas do osso ou em pacientes que tomam certos medicamentos), ou sofrem sobrecargas constantes sem que haja tempo suficiente para uma resposta reparadora (por exemplo, durante treinamentos físicos intensos), os ossos podem exibir fratura por fadiga depois de vários ciclos de carregamento (STANITSKI et al, 1978).

Sob certas condições patológicas, o osso pode falhar antes de sofrer deformação permanente, sem exibir plasticidade (capacidade de deformar-se permanentemente). Quando o ponto de escoamento e o ponto de ruptura coincidem, é dito que o osso é frágil. Quando esses dois pontos não coincidem, o osso exibe

${ }^{19}$ HAYES, W.C. (1993). Biomechanics of bone: Implications for assessment of bone strength ASMBR Workshop, Kelseyvile 1-18. 
dutilidade, onde parte da energia usada para produzir a deformação permanente é recuperada e parte não é. A estrutura molecular do material é reorganizada em uma configuração nova e estável, e a forma externa do corpo de prova não reverte ao que era originalmente. Materiais semelhantes à borracha, como calos de fraturas não consolidadas completamente, são capazes de resistir à deformação elástica por muito tempo sem se romper. Nestes casos, não ocorre deformação permanente. Um material frágil devido o seu módulo de elasticidade e sua resistência serem altos, não mostra deformação significante antes da ruptura, enquanto que um material flexível absorve uma quantidade igual de energia sofrendo deformação plástica significante antes de romper (EINHORN, 1996).

Materiais biológicos possuem elementos estruturais orientados de várias formas e com propriedades mecânicas que lhes permitem suportar cargas em condições diferentes. As propriedades mecânicas do osso, por exemplo, não só variam de acordo com natureza da força aplicada, mas, também, de acordo com seu sentido e taxa de aplicação. Materiais ideais são regulares e sempre se comportam da mesma maneira, independentemente do sentido da força aplicada. Os ossos, entretanto, possuem propriedades diferentes para sentidos diferentes de aplicação de carga. Esse fenômeno é conhecido como anisotropia. Outros materiais são isotrópicos, i.e., embora o sentido da carga aplicada seja diferente, suas propriedades mecânicas não se alteram (TURNER et al, 1995). A natureza anisotrópica do osso é documentada por meio dos dados obtidos das propriedades materiais do osso cortical e do osso trabecular, em vários tipos de carregamento. Esta propriedade do osso pode ser ilustrada pela aplicação de uma carga ao fềmur. Considerando sua orientação vertical, ele está sujeito a uma carga de compressão ou tração e é, então, capaz de resistir ao carregamento de compressão axial, sem mostrar deformação permanente. Porém, a mesma carga aplicada em uma direção transversal causa tensões de flexão tão altas que não serão toleradas pelo fềmur da mesma maneira, podendo resultar em fratura. Assim, a resistência e a rigidez do osso são maiores na direção de carregamento habitual. Isto é particularmente verdadeiro no osso cortical onde os ósteons são orientados longitudinalmente (HERT et al, 1994).

Outra propriedade mecânica importante exibida pelo tecido ósseo é conhecida como viscoelasticidade. As propriedades mecânicas de um material 
viscoelástico diferem de acordo com a taxa e velocidade de carregamento. Este fenômeno se deve ao fato do osso ser um material que flui internamente quando submetido à aplicação de uma carga. Um aumento da taxa de carregamento (ou deformação) aumenta o módulo de elasticidade e a força máxima do osso cortical enquanto que diminui a deformação máxima. Diante de baixas taxas de deformação o osso não mostra nenhuma deformação elástica apreciável mas bastante fluência, como um líquido viscoso. Diante de altas taxas de deformação o mesmo osso pode se comportar como material sólido frágil. Por causa destas características devem ser especificadas a taxa de deformação e a direção da carga aplicada, quando o comportamento de material ósseo for descrito (EINHORN, 1992).

\section{ENSAIOS MECÂNICOS}

Os ensaios mecânicos permitem determinar as propriedades mecânicas de um material. Eles podem ser destrutivos, quando promovem a ruptura ou a inutilização do material ou não destrutivos, em caso contrário. Na primeira categoria estão os ensaios de compressão, flexão, tração, torção, fadiga e outros. Dentre os ensaios não destrutivos podem ser destacados os raios $\mathrm{X}$ e o ultra-som (SOUZA, 1974).

A escolha do ensaio mecânico mais interessante ou adequado para cada material depende da finalidade do material, dos tipos de esforços que ele sofrerá e das propriedades mecânicas que se pretende medir. Dois fatores determinantes para a realização de um tipo de ensaio mecânico são a quantidade e o tamanho das amostras a serem testadas. Alguns dos ensaios mencionados permitem obter dados ou elementos numéricos que podem ser utilizados no cálculo das tensões de trabalho e no projeto de uma peça. Outros fornecem apenas resultados comparativos ou qualitativos do material e servem somente para auxiliar ou completar o estudo ou o projeto (SOUZA, 1974).

Os ensaios mecânicos de materiais em condições laboratoriais, envolvem o conhecimento das forças e as medidas das deformações por elas produzidas. Sabendo o tamanho do corpo de prova, a força aplicada, e a deformação produzida, as 
propriedades mecânicas podem ser obtidas a partir do gráfico da tensão $x$ deformação (EINHORN, 1996).

A Máquina Universal de Ensaio (MUE) é utilizada para estes testes. São obtidos os valores para a carga aplicada e as medidas da deformação correspondente. Com estes parâmetros podem ser construídos os gráficos tensão $x$ deformação.

Por convenção, tensão é registrada na ordenada (eixo y) e a deformação na abscissa (eixo x) (FIGURA 6).

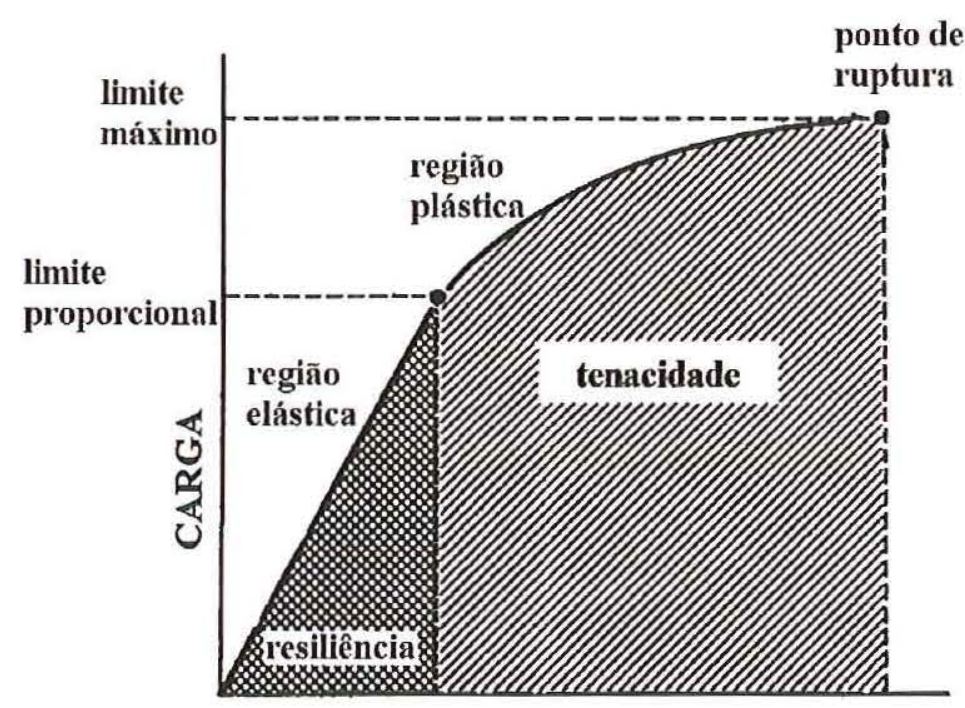

DEFORMAÇÃO

FIGURA 6. Curva padrão carga x deformação. (Fonte: EINHORN, 1996)

Desde que estas tensões sejam produzidas externamente por diferente forças aplicadas (tração, compressão, flexão, torção), o eixo y poderá representar qualquer destas condições de carregamento, com uma curva resultante da relação de carga $x$ deformação (EINHORN, 1996), onde a tensão ( $\sigma$ ) é a força aplicada (F) dividida pela área da secção transversal do corpo de prova (A) (TIMOSHENKO, 1967).

$$
\sigma=\frac{F}{A}
$$

A deformação relativa (ع) é a variação de uma dimensão qualquer desse corpo, por unidade da mesma dimensão, quando esse corpo recebe a aplicação de uma carga. 


$$
\varepsilon=\frac{\Delta L}{L_{0}}
$$

onde Lo é o comprimento inicial do corpo de prova e $\Delta \mathrm{L}$ é a variação do comprimento, ou seja, quanto alterou em relação ao comprimento inicial.

A curva de tensão pode ser analisada em regiões para se obterem as diferentes propriedades materiais de osso. Assim, a baixos níveis de tensão, há uma relação linear entre a tensão aplicada e a deformação resultante. Esta proporcionalidade é chamada de módulo de elasticidade ou módulo de Young. É uma medida da inclinação da porção linear da curva e é calculada dividindo a tensão pela deformação, em qualquer ponto ao longo desta porção da curva (FIGURA 8) (EINHORN, 1996).

\subsection{Ensaios estáticos}

Os ensaios estáticos utilizam corpos de prova ou estruturas intactas, aplicando incremento de força em pequenas velocidades, com o objetivo de obter as propriedades mecânicas desejadas aplicando as equações da estática. Estas propriedades ajudam a entender o comportamento destes materiais, quando submetidos a cargas estáticas e, a calcular a resistência destes materiais mediante um determinado carregamento estático.

\subsubsection{Ensaio de compressão}

Os ensaios mecânicos estáticos mais comuns e mais simples são os de tração e de compressão, em face da facilidade de execução. Eles fornecem as propriedades mecânicas básicas para o cálculo da resistência de um material como módulo de elasticidade e resistência à tração e compressão. 
Os ensaios de compressão são realizados pela aplicação de carga axial $P$ para comprimir o corpo de prova (FIGURA 7). À medida que a carga $P$ aumenta, ocorre um achatamento do material, que é anotado para cada valor de $P$. A seleção do ensaio de compressão, ao invés de outros tipos de ensaio, é determinada pelo tipo de carregamento que o material está sujeito. Metais, por exemplo, são mais resistentes à tração quando comparados com outros materiais, como o concreto. Os metais, por isso, são mais comumente testados à tração. Materiais frágeis como concreto e a maioria dos produtos cerâmicos possuem baixa resistência à tração, quando comparada com sua resistência à compressão. Daí o seu emprego para resistir a cargas compressivas (HORATH, 1995).

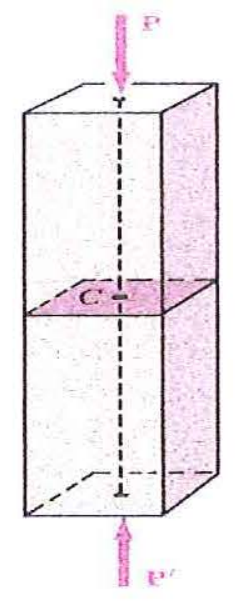

FIGURA 7. Representação esquemática mostrando o sentido de aplicação da carga no ensaio de compressão (Fonte: BEER \& JOHNSTON Jr., 1992).

Colocando, então, cada incremento de carga com a respectiva deformação em um gráfico, obtém-se o diagrama tensão x deformação (FIGURA 8) adotando-se deformação (d) como abscissa e carga (C) como ordenada. A partir do diagrama, é possível obter as principais propriedades mecânicas dos materiais como a rigidez, a resistência à compressão, o limite de proporcionalidade e o limite de ruptura. 


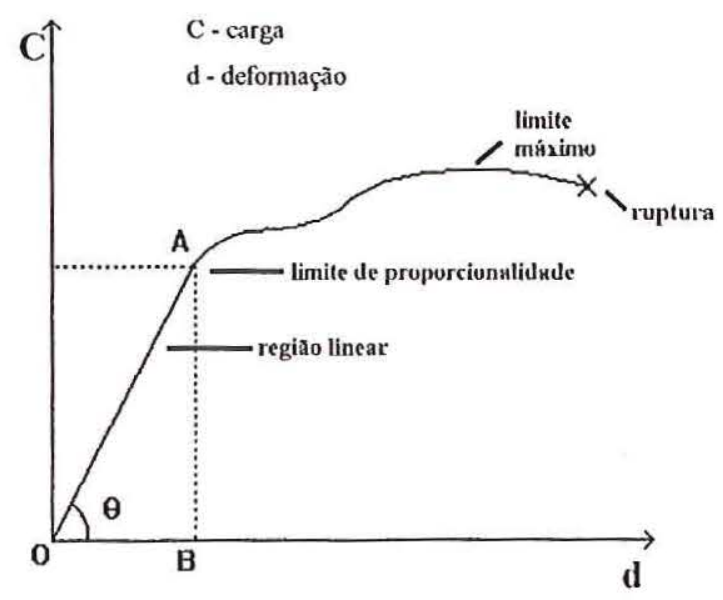

FIGURA 8. Diagrama carga $x$ deformação para o ensaio de compressão. (Fonte: EINHORN, 1996)

A porção linear da curva de tensão $x$ deformação é conhecida como região elástica. A partir do ponto onde a curva deixa de ser linear, recebe o nome de região plástica e a tensão máxima suportada pelo material é neste momento conhecida como limite elástico do material. $\mathrm{O}$ ponto na curva onde isto acontece é conhecido como escoamento. $\mathrm{O}$ carregamento do material além do ponto de escoamento resultará em sua deformação permanente. Esta propriedade é conhecida como plasticidade. Na região elástica, a deformação de um material ocorrerá apenas enquanto a carga está sendo aplicada. Uma vez retirada a carga, o material readquire sua forma e dimensões originais. Se a carga aplicada ultrapassar o limite elástico do material, ou ponto de escoamento, mesmo após sua remoção o material terá sofrido deformação permanente, com perda das suas dimensões iniciais (EINHORN, 1996).

\subsubsection{Rigidez}

A rigidez é obtida pelo cálculo da inclinação da curva carga $x$ deformação na região linear. Quanto maior a rigidez, menor a deformação elástica resultante da aplicação de uma tensão e mais rígido é o material. A rigidez é dada pela equação:

$$
R=\operatorname{tg} \theta=\frac{\Delta C}{\Delta d}
$$




\subsubsection{Limite máximo}

O limite máximo é utilizado como mais um critério de avaliação da resistência, e é o maior valor da tensão com a deformação correspondente observada em cada ensaio (ponto máximo).

\subsubsection{Limite de proporcionalidade}

O limite de proporcionalidade é o ponto de término da relação linear entre a tensão e a deformação no gráfico tensão $x$ deformação.

\subsubsection{Limite de ruptura}

O limite de ruptura corresponde ao ponto de ruptura do material.

O comportamento elástico de um material quando sujeito à carga de compressão é comparável ao seu comportamento elástico quando sujeito à tração. Essa afirmação aplica-se principalmente a materiais dúcteis que, na fase elástica, sob a ação da compressão, obedecerá também à lei de Hooke. Na fase plástica, ainda no caso dos materiais dúteis, não há mais possibilidade de comparação, porque a medida que aumenta a carga de compressão, a peça sob a ação de esforço crescente, tende a ter a sua seç̧ão transversal alargada, achatando-se na forma de um disco, sem que ocorra a sua ruptura (CHIAVERINI, 1977).

A ruptura ocorre na maioria dos materiais frágeis. Para estes verifica-se que não ocorrem deformações laterais e com cargas de compressão crescentes, resulta uma tensão que provoca a ruptura por cisalhamento e deslizamento ao longo de um plano inclinado (FIGURA 9) (CHIAVERINI,1977). 


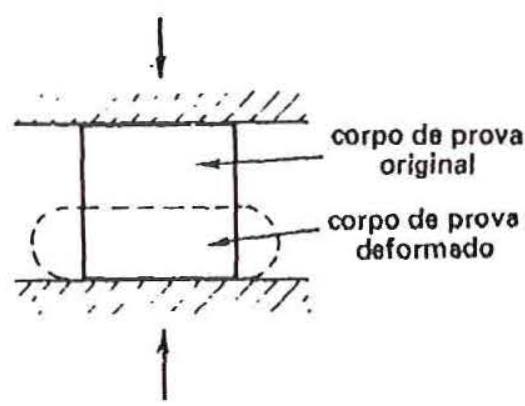

Material dúctil

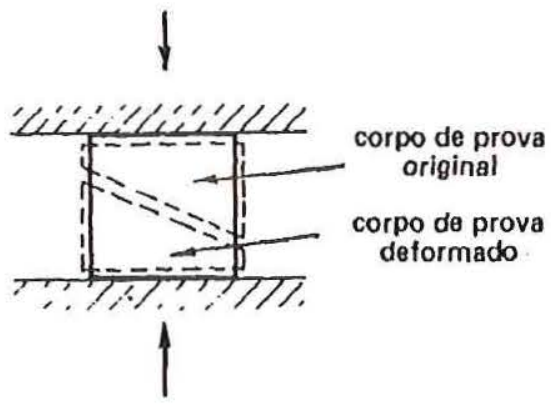

Material frógil

FIGURA 9. Comportamento de material dúctil e frágil sob compressão.

No ensaio de compressão realizado em materiais dúteis, não é possível determinar as propriedades mecânicas na faixa plástica, enquanto que as propriedades elásticas como módulo de elasticidade, limite de escoamento, limite de proporcionalidade e resiliência podem ser determinados como no ensaio de tração (CHIAVERINI, 1977).

\subsubsection{Ensaio de flexão}

A determinação das tensões e deformações provocadas pela flexão de um material no regime elástico é importante no estudo da resistência dos materiais. A maioria das estruturas está sujeita à flexão e, por isso, há necessidade de testes de laboratório para determinação das propriedades de flexão (BEER \& JOHNSTON, $1981)$.

Na determinação das propriedades de flexão de um material, uma curva carga $x$ deflexão é obtida usando o arranjo de carregamento como mostrado na FIGURA 10. 


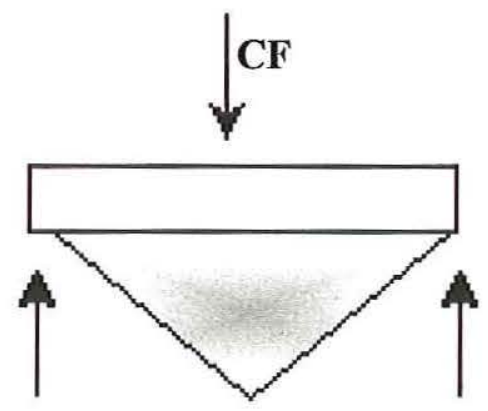

FIGURA 10. Configuração do carregamento no ensaio de flexão.

Colocando cada incremento de carga com a respectiva deflexão em um gráfico, obtém-se o diagrama carga $x$ deflexão (FIGURA 11), adotando-se $d$ como abscissa e $C$ como ordenada..

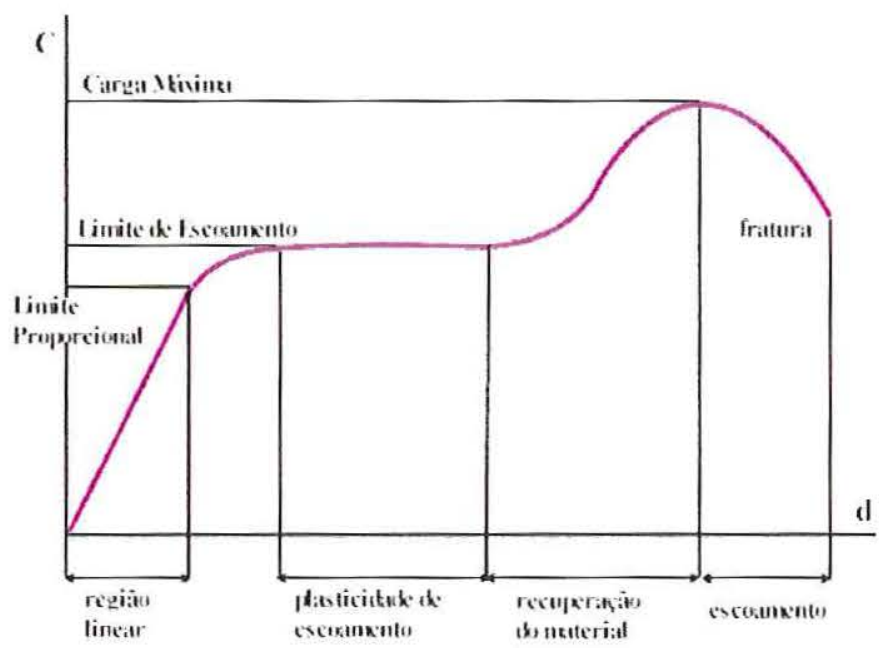

FIGURA 11. Curva carga $x$ deflexão do ensaio de flexão.

\subsubsection{Rigidez}

A rigidez é obtida pelo cálculo da inclinação da curva carga $\mathrm{x}$ deflexão na região linear e é dada pela equação:

$$
\mathbf{R}=\frac{\Delta \mathbf{C}}{\Delta \mathbf{d}}
$$




\subsubsection{Limite máximo}

O limite máximo é utilizado como mais um critério de avaliação da resistência, e é o maior valor da carga com a deflexão correspondente observada em cada ensaio (ponto máximo).

\subsubsection{Limite de proporcionalidade}

O limite de proporcionalidade é o ponto de término da relação linear entre a carga e a deformação no gráfico carga x deflexão.

\subsubsection{Limite de ruptura}

O limite de ruptura corresponde ao ponto de falha do material.

O ensaio de flexão provê uma estimativa da dutilidade do material a ser testado. Nos materiais frágeis, como cerâmicas e materiais compósitos, o ensaio de tração não deve ser realizado, pelo fato das garras quando fixadas aos corpos de prova provocarem pequenas falhas que se propagam e provocam a falha do material, invalidando o ensaio. Nestas situações, o ensaio de flexão é utilizado para determinar a resistência e o módulo de ruptura do material (HORATH, 1995). 


\subsection{Ensaios Mecânicos do Osso}

A área da Bioengenharia que estuda as propriedades mecânicas em tecidos biológicos é a Biomecânica, que é entendida como sendo a aplicação das leis da Mecânica aos sistemas biológicos.

Uma vez que o esqueleto funciona como um sistema que suporta cargas e é submetido a um complexo de forças causadoras de deformações (McALISTER \& MOYLE, 1983), a Biomecânica apresenta-se como um valioso instrumento de medida no estudo e compreensão desses eventos e suas conseqüências atuando, portanto, como elo fundamental entre as ciências exatas e as biológicas, particularmente para a Ortopedia, Traumatologia e Reabilitação, possibilitando uma oportunidade que permitiu estudos multidisciplinares e interação entre profissionais de diferentes formações ( PESSAN, 1996).

A importância das propriedades mecânicas fez com que, em 1640, GALILEU GALILEI iniciasse os estudos das características mecânicas em ossos longos de vários animais. A partir desta data, vários autores, utilizando cada qual uma determinada técnica e objetivo, buscaram maiores informações e conhecimento do osso como material biológico (SHIMANO, 1994).

Mecanicamente, o osso pode ser estudado como material (tecido ósseo) ou como estrutura intacta (por exemplo, o fêmur), sendo que ambos estudos possuem finalidades distintas (EVANS, 1982).

Quando há interesse no conhecimento das propriedades do tecido, amostras são retiradas do osso e ensaiadas. Assim, é possível caracterizar o tecido ósseo por meio da curva tensão $x$ deformação. Dependendo do ensaio, pode-se determinar outras propriedades como: módulo de elasticidade, módulo de cisalhamento, limite de resistência e limite de rotura. Estes parâmetros são importantes pois ajudam a caracterizar um elemento biológico que tem grande importância na absorção, transmissão e resistência aos esforços físicos. Entretanto, o que se observa na literatura é que há grande variação de resultados que dependem de fatores como o osso que foi utilizado (p.ex.: fêmur, tíbia, úmero), a região do osso estudada (epífise, 
metáfise e diáfise), condições em que a amostra foi recolhida e ainda, o animal em estudo e o tipo de tratamento que ele recebeu (SEDLIN, 1966). Essas variações, em parte, advêm do fato de que o osso é um material viscoelástico (COWIN, 1989), heterogêneo e anisotrópico ( REILY et al., 1974).

$\mathrm{O}$ estudo do osso como uma estrutura intacta é interessante uma vez que os resultados refletem melhor a capacidade do sistema músculo-esquelético "in vivo", sua função como alavanca e a capacidade para resistência aos esforços, em várias condições (HAYES \& CARTER, 1971).

O ensaio de ossos inteiros, contudo, não é uma tarefa fácil pois eles são elementos complexos do ponto de vista espacial apresentando grandes variações estruturais, dada a íntima relação existente entre a função que desempenham e as solicitações mecânicas a que estão submetidos, o que torna dificil a padronização do ensaio.

Os ensaios de flexão são importantes na biomecânica pois fornecem parâmetros fundamentais das propriedades mecânicas dos ossos, como a rigidez e a resistência mecânica (SINKIN \& ROBIN, 1973). Estes e outros parâmetros podem ser também obtidos nos ensaios de compressão.

$\mathrm{O}$ estudo da anatomia comparada de diversos animais mostra que um achado constante é o encurvamento anterior da diáfise da tíbia. Isto ocorre nos mamíferos mais comuns, tanto de laboratório (coelho, camundongo, rato) como nos animais domésticos (cão, gato), em aves e até mesmo em répteis. Essa alteração na estrutura do osso reflete as solicitações mecânicas locais que pela resultante das forças, tendem a provocar um esforço de flexo-compressão do osso no sentido póstero-anterior.

ENGESAETER, EKELAND, LANGELAND (1978) ao medirem as propriedades de flexão torsional do fêmur de rato concluíram que, sendo o osso um material biológico, portanto, não homogêneo, quando submetido a testes mecânicos podem-se cometer erros.

REILLY et al. 1974, verificaram que, pelo fato do osso ser um material anisotrópico, suas propriedades elásticas diferem de acordo com a direção em que o ensaio foi realizado. 
ABRAM, KELLER, SPENGLER (1988) investigaram as mudanças histomorfométricas e mecânicas do osso que ocorrem sem a ação do peso corporal. Foram utilizados pares de membros traseiros de ratos machos, dividindo-os em dois grupos. Um grupo ficou sob peso simulado e o outro grupo ficou suspenso. Eles realizaram teste estático e dinâmico de flexão e torção em fềmures intactos e compararam os dois grupos. O grupo experimental apresentou baixa geometria e menores propriedades materiais, com resultante hipotrofia estrutural e mudanças geométricas e materiais do osso.

KELLER, SPENGLER, CARTER (1986) avaliaram a área de seç̧ão transversal em fềmures de ratos machos com idades compreendidas entre 22 e 311 dias, realizando testes de flexão e torção. Observaram que todas as propriedades materiais e estruturais aumentaram com o aumento da idade. Com isso, concluíram que as propriedades estruturais do osso são reguladas por alteração das propriedades materiais e geométricas.

TORZILLI et al. (1982) determinaram as propriedades mecânicas e geométricas de ossos longos de cães em crescimento, com testes de flexão em três pontos. Eles verificaram que as propriedades estruturais dependeram do material (módulo elástico), geometria (seç̧ão transversal, área e momento de inércia) e propriedades morfológicas do osso. Os autores constataram, ainda, que, com o aumento de idade, os ossos ficaram mais rígidos, com capacidade de resistir à maior quantidade de carga, indicando que existe uma forte relação entre a resposta mecânica e o desenvolvimento morfológico do osso.

CURREY \& BUTLER (1975) realizaram teste de flexão em espécimes de osso cortical femoral em humanos, entre 2 e 48 anos de idade. Comparados com osso de adultos, os de criança se mostraram mais plásticos, com maior capacidade de absorção de energia antes da quebra e após iniciada a fratura.

TORZILLI et al. (1982), em trabalhos com cães, investigaram as mudanças que ocorrem na morfologia e propriedades materiais da maturação do esqueleto. Estudaram: a) geometria do osso, i.e., comprimento e área da secção transversal. b) propriedades do tecido material em tração e compressão. c) quantidade e qualidade das propriedades morfológicas, mediante preparações químicas. Eles observaram que, durante o crescimento até que amadureça, ocorre aumento de esforço no osso. 
Entretanto, com aumento de idade, além da maturação, ossos em cães exibiram uma lenta diminuição nas propriedades mecânicas.

CARTER \& SPENGLER (1978) constataram que, o osso cortical e o osso esponjoso podem ser considerados um material que apresenta várias densidades. $\mathrm{O}$ osso cortical apresentou-se muito mais resistente à compressão do que à tração e verificaram que, no adulto, ósteons com fibras colágenas orientadas transversalmente mostraram-se muito mais resistentes à compressão do que ósteons com fibras orientadas longitudinalmente e ósteons com fibras colágenas orientadas longitudinalmente se mostraram muito mais resistentes à tração do que ósteons com fibras orientadas transversamente.

DEMPSTER \& LIDDICOAT (1952) estudaram a curva tensão $x$ deformação para o osso úmido compacto. Eles determinaram o módulo de elasticidade em três direções (longitudinal, transversal e radial) para um pequeno cubo de osso humano (fêmur, tíbia e úmero) e não encontraram diferença estatisticamente significante para o módulo de elasticidade nas direções radial (superficie medular) e transversal (dentro do plano de isotropia), porém, os módulos na direção longitudinal estavam aproximadamente duas vezes maior.

MATHER et al (1967) testaram, em flexão, fêmures humanos frescos até a rotura, comparando os lados direito e esquerdo para estudar as propriedades mecânicas em relação ao lado. Verificaram, neste estudo, que a média da carga máxima suportada por uma série de fềmures direitos não apresentou diferença significativa em relação aos fềmures esquerdos da mesma espécie. Em outro estudo, MATHER et al (1967) testaram, em flexão, fêmures humanos frescos e mediram a energia absorvida e o módulo de elasticidade. Os fêmures foram simétricos para essas duas propriedades mecânicas.

HOYER \& LIPPERT (1982) determinaram propriedades mecânicas do fêmur, tíbia e úmero, testados em flexão. Foram estudados ossos de ratos, machos e fêmeas, com idade de 35 a 1129 dias pós-natal. Os valores médios de peso, comprimento do osso e dados mecânicos foram significativamente maiores em ratos machos e, em ambos os sexos, tiveram clara dependência da idade. Nos animais com idade acima de 330 dias, a tíbia se apresentou mais flexível do que o fêmur ou o 
úmero. Os autores observaram, ainda, que não houve diferença nas propriedades mecânicas entre ossos frescos e osso congelados.

SIMKIN \& ROBIN (1973) realizaram testes de compressão, flexão, e tração em amostras de osso cortical retiradas da face anterior de tíbias de bovinos. O módulo de elasticidade aumentou com a proporção comprimento $x$ largura.

SEDLIN \& HIRSCH (1966) utilizaram amostras obtidas da região diafisária de fêmures humanos adultos que foram ensaiadas em flexão e tração após terem sido armazenadas em solução fisiológica a $-20^{\circ} \mathrm{C}$. Verificaram que os parâmetros mecânicos em ensaios de flexão podem ser influenciados pela distância entre os suportes utilizados e por agentes químicos e físicos como o estado de hidratação, congelamento e tipo de fixação. Constataram, também, que as propriedades variaram conforme a região do osso das quais as amostras foram retiradas.

GRUNDNES \& REIKERAS (1992) aplicaram teste de flexão em três pontos em fềmures intactos de ratos Wistar, após terem sido exercitados durante seis semanas em um círculo giratório. Verificaram que o momento máximo de flexão foi maior nos ratos exercitados, indicando que os exercícios afetaram as características mecânicas do osso, assim como a máxima flexão e rigidez.

PESSAN (1996) analisou o comportamento mecânico de fềmures de ratas imaturas e próximas da maturidade, realizando ensaios de flexão, com forças aplicadas nas faces côncava e convexa destes ossos, após terem sido mantidos sob temperatura de $-20^{\circ} \mathrm{C}$, durante 30 dias. Foram analisadas os seguintes parâmetros: tensão máxima, módulo de elasticidade equivalente, tensão no limite de proporcionalidade e energia absorvida na fase elástica, para as duas idades de ratas ensaiadas. Da análise dos resultados conclui-se que ratas mais próximas do crescimento têm ossos com maior resistência aos esforços de flexão. Conseqüentemente, todos os parâmetros mecânicos foram significativamente maiores para os animais mais maduros. Esse autor observou, também que, não houve diferença significativa fosse a força aplicada na face côncava ou convexa dos fêmures. 


\section{MATERIAL E MÉTODO}

\subsection{Seleção dos Animais}

Foram utilizadas tíbias e fíbulas retiradas de ratos da raça Rattus Norvegicus albinus, variedade Wistar fornecidos pelo Biotério Central do Campus da Universidade de São Paulo em Ribeirão Preto. Todos os ratos eram machos, adulto jovens, com peso corporal médio de $350 \mathrm{~g}$. Foram utilizados 20 animais para os ensaios de compressão e 20 animais para os ensaios de flexão com as mesmas características físicas.

\subsection{Ensaios Mecânicos de Compressão}

\subsubsection{Preparo dos Modelos de Prova (das tíbias e fíbulas)}

Os animais foram sacrificados com inalação de éter sulfúrico. Em seguida, os membros traseiros foram dissecados e as unidades tíbio-fíbulares retiradas e limpas das partes moles circundantes. O periósteo e a cartilagem articular de ambos os ossos em ambas as extremidades, como também a articulação tíbio-fibular proximal, foram preservados. Um cuidado especial foi tomado na dissecação dos músculos que possuem inserção na cabeça e região proximal da fibula (flexor longo do primeiro dedo, flexor longo dos dedos, tibial posterior, fibular longo e curto, fibular do quarto e quinto dedos), em especial o músculo solear, uma vez que ele se origina na cabeça da fibula por meio de um tendão (GREENE, 1963) que, se tracionado para cima provoca a separação entre o osso e a cartilagem articular e conseqüentemente, a desarticulação da unidade tíbia-fíbula, proximalmente. 


\subsubsection{Confeç̧ão do Suporte para Inclusão dos ossos em resina acrílica}

Para o ensaio de compressão a região distal de cada unidade tíbio-fibular foi incluída em resina acrílica de uso odontológico, fixando-a. Foi padronizada uma medida $(28 \mathrm{~mm})$ a partir da cabeça da tíbia, para que apenas os dois terços distais (sítio da união tíbio-fibular) ficassem incluídos na resina. Para a realização da inclusão, logo após terem sido pesadas e medidas, cada unidade tíbio-fibular teve sua extremidade proximal fixada em um suporte de latão confeccionado na Oficina de Precisão da Prefeitura do Campus da Universidade de São Paulo em Ribeirão Preto (FIGURA 12), com o qual foi possível controlar o alinhamento dos ossos e o paralelismo de suas extremidades. Só após isso, a extremidade distal foi mergulhada em resina. Para evitar o aquecimento excessivo durante o processo de polimerização, a resina foi mantida resfriada com água gelada. Durante todos esses procedimentos os ossos foram mantidos umidecidos com soro fisiológico.

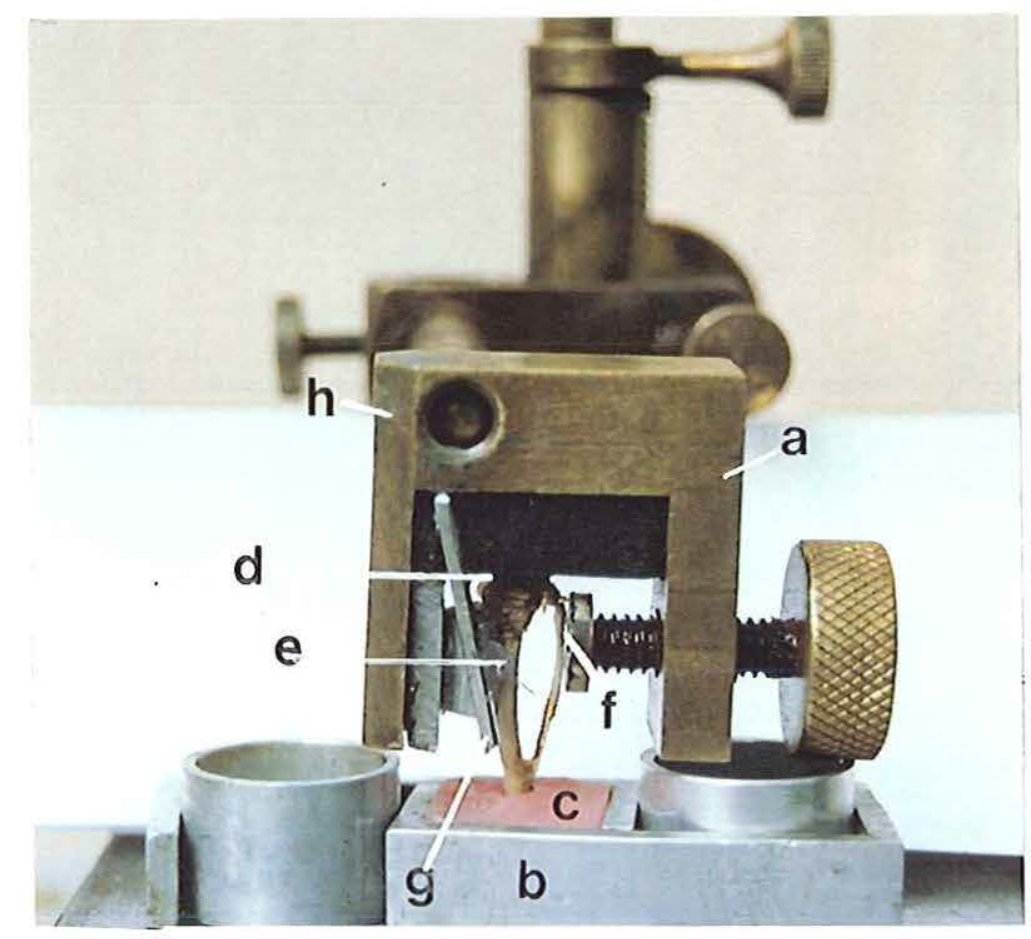

FIGURA 12. Inclusão das unidades tíbio-fibulares em resina acrílica a-Suporte de latão, b-acessório de alumínio para moldagem da resina, c-resina acrílica. Pontos de referência para padronização do alinhamento: d- Apoio do planalto superior da tíbia, e-apoio da face ântero-superior da tíbia, f-apoio posterior da fibula, g-fio de Kirschner (controle do alinhamento ântero-posterior da diáfise da tíbia ), h-marcação lateral (controle do alinhamento látero-lateral da tíbia). 
Após o endurecimento da resina os modelos de prova foram retirados do suporte, identificados, envolvidos em gase umedecida em soro fisiológico, colocados em recipientes plásticos e armazenados em "freezer" sob temperatura de $-20^{\circ} \mathrm{C}$, por um período de 24 horas.

\subsubsection{Confecção dos Acessórios}

Para melhor visualização dos eventos na região proximal da tíbia durante o ensaio de compressão, uma peça móvel de resina odontológica foi moldada e utilizada como base de apoio para o planalto tibial.

\subsection{Realização do Ensaio Mecânico de Compressão}

Para os ensaios mecânicos foi utilizada a máquina universal de ensaio do Laboratório de Bioengenharia da Faculdade de Medicina de Ribeirão Preto da Universidade de São Paulo. Os modelos de prova congelados foram retirados do "freezer" 24 horas antes dos ensaios e mantidos em um refrigerador. Algumas horas antes de serem testados, os modelos foram retirados e mantidos em temperatura ambiente para entrarem em equilíbrio térmico com o meio ambiente, ainda envolvidos com gase umedecida em soro fisiológico.

Os modelos de prova foram, então, submetidos ao ensaio de compressão (FIGURA 13) sendo que, dentre os vinte pares utilizados, em 10, a fibula do lado direito foi mantida e do lado esquerdo removida; nos outros 10 , o procedimento foi inverso. O lado sem fibula, portanto, serviu sempre como controle e a comparação foi entre ossos de um mesmo animal. No momento do ensaio foram tomados cuidados para manter o paralelismo e o alinhamento da peça tomando como referência a tíbia.

A carga foi aplicada a uma velocidade de $0,10 \mathrm{~mm} / \mathrm{min}$ e registrada por uma célula de carga KRATOS®, modelo KM, de $200 \mathrm{kgf}$, acoplada ao amplificador 
CAE 201 SODMEX®. As deformações foram registradas por um relógio comparador com precisão de um centésimo de milímetro.

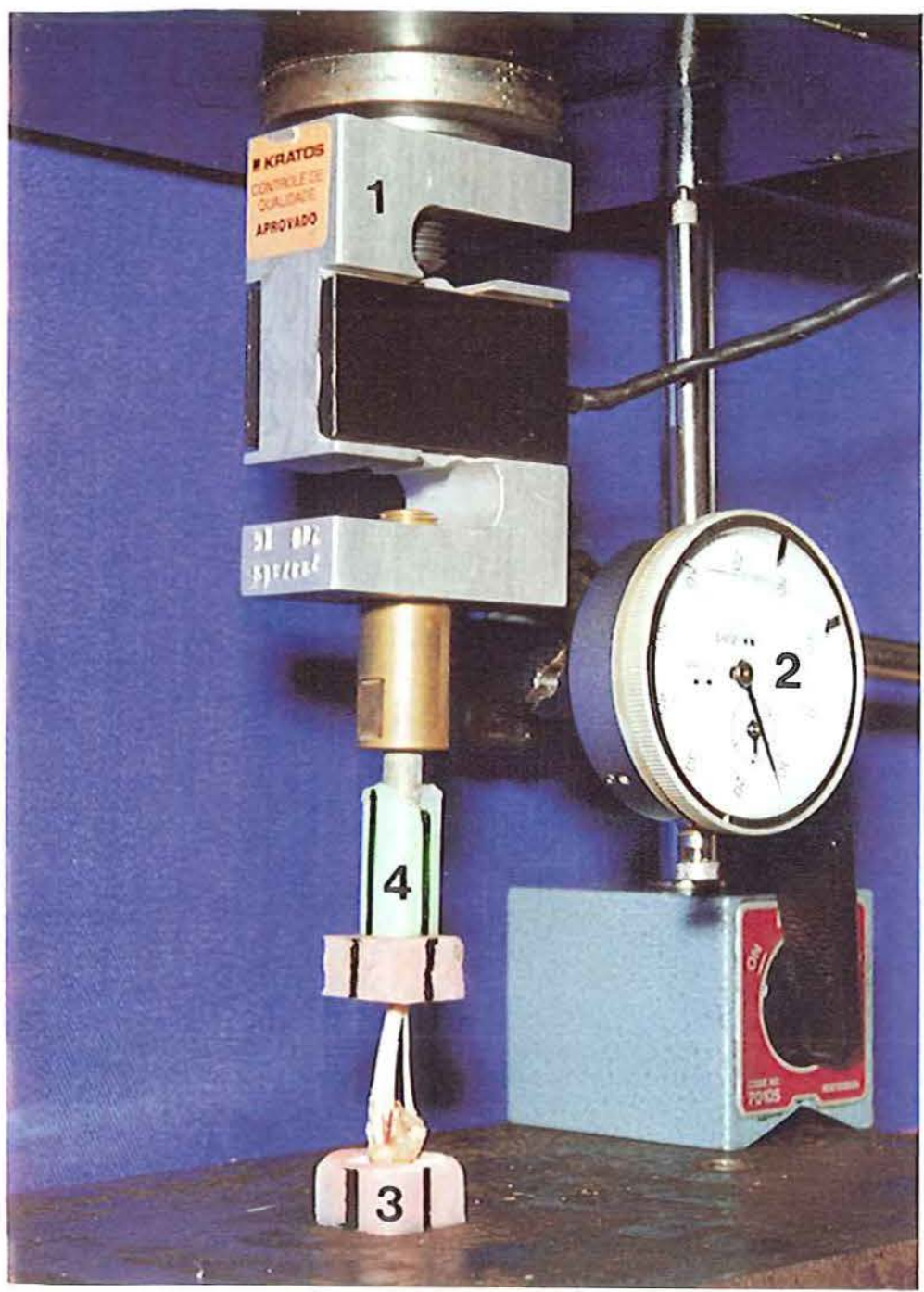

FIGURA 13. Montagem do ensaio de compressão axial em unidades tíbio-fibulares de rato. 1-Célula de carga, 2- relógio comparador, 3- base de apoio (resina acrílica), 4- acessório para aplicação da carga.

Foi aplicada uma pré-carga de $0,5 \mathrm{kgf}$, com tempo de acomodação do sistema de 30 segundos. As cargas foram aplicadas axialmente aos modelos, aplicando força de compressão até a rotura. Todos os ensaios foram realizados em condições semelhantes e os ossos foram mantidos umedecidos em soro fisiológico para evitar o ressecamento. 


\subsection{Ensaios de Flexão em três Pontos}

\subsubsection{Obtenção das Amostras}

Os procedimentos para a obtenção, pesagem, medição, armazenamento e preparo das tíbias e fíbulas utilizadas para os ensaios de flexão em três pontos seguiram a mesma técnica descrita anteriormente para os ensaios de compressão. Entretanto, neste caso, não houve a necessidade de inclusão das peças ósseas em resina.

\subsubsection{Confecção do Acessório Mecânico}

O acessório utilizado para o ensaio de flexão foi confeccionado em latão (FIGURA.13) na Oficina de Precisão da Prefeitura do Campus da Universidade de São Paulo em Ribeirão Preto.

A distância padronizada entre os apoios foi de $28 \mathrm{~mm}$.

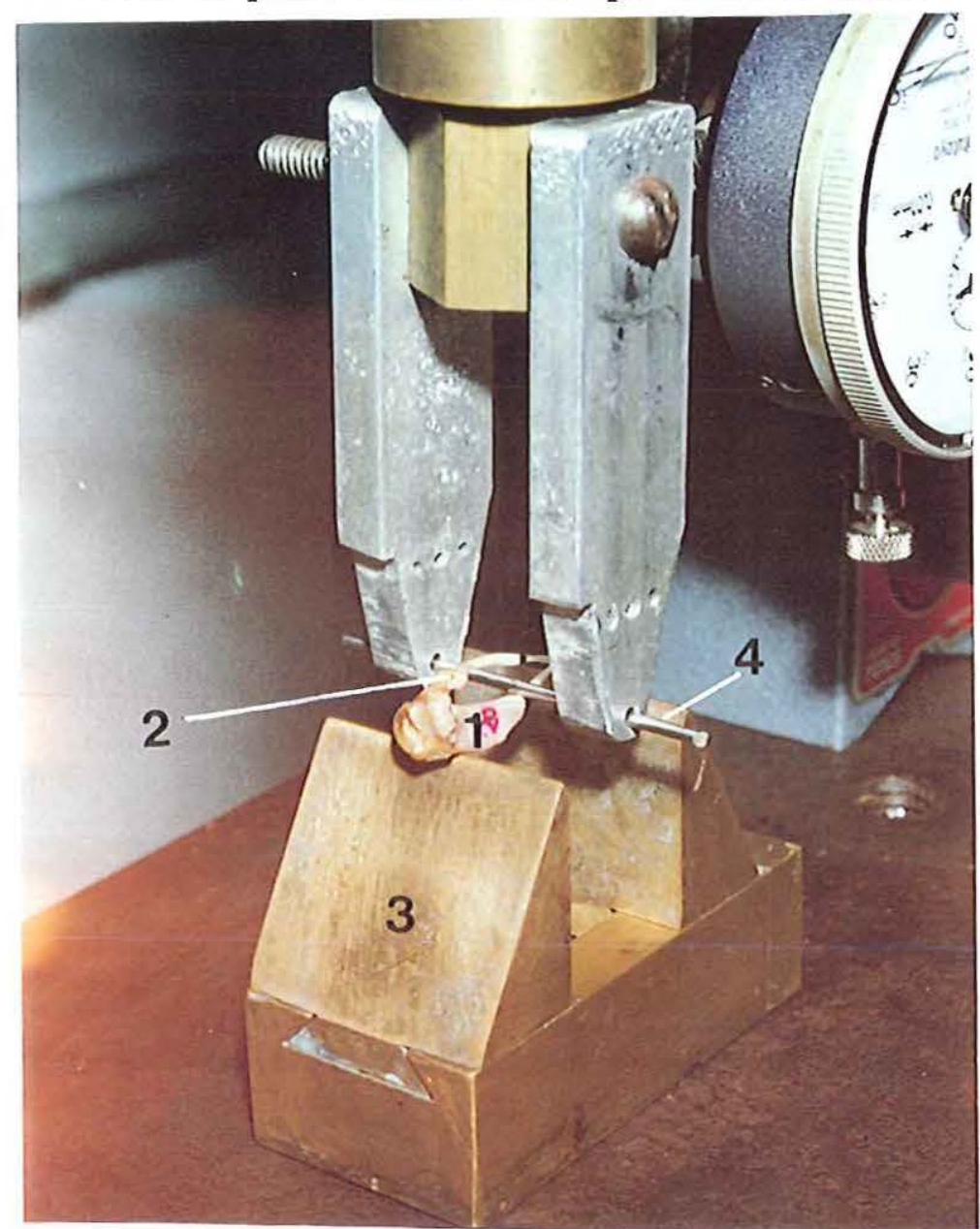

FIGURA 14. Acessório mecânico utilizado no ensaio de flexão em três pontos. 1Tíbia de rato, 2-fibula de rato, 3- acessório de apoio, 4- acessório de aplicação de carga (fio de Kirschner). 


\subsection{Realização do Ensaio Mecânico de Flexão em três Pontos}

Os ensaios mecânicos foram realizados no Laboratório de Bioengenharia da Faculdade de Medicina de Ribeirão Preto da Universidade de São Paulo. Os corpos de prova congelados foram retirados do "freezer" 24 horas antes do ensaio e mantidos em um refrigerador. Retirados algumas horas antes do teste, os modelos foram mantidos em temperatura ambiente para entrarem em equilíbrio térmico com o meio, permanecendo envolvida com gase umedecidos em soro fisiológico.

Foi utilizada a mesma máquina universal de ensaio do Laboratório de Bioengenharia da Faculdade de Medicina de Ribeirão Preto da USP.

Os corpos de prova foram submetidos à flexão simples com três pontos de apoio (FIGURA 14). Dentre os vinte pares utilizados, em 10, a fibula do lado direito foi preservada e, no lado esquerdo, removida. Nos outros 10 pares o procedimento foi inverso. O lado sem fibula, portanto, serviu sempre como controle. Cuidado foi tomado para evitar que houvesse deslizamento dos ossos sobre os acessórios e para manter sempre o alinhamento dos mesmos. A carga foi aplicada a uma velocidade de $0,15 \mathrm{~mm} / \mathrm{min}$ e registrada por uma célula de carga $\mathrm{KRATOS}^{\circledR}$, modelo KM, de 200 kgf, acoplada ao amplificador CAE 201 SODMEX $^{\circledR}$. As deformações foram registradas por um relógio comparador com precisão de um centésimo de milímetro. 


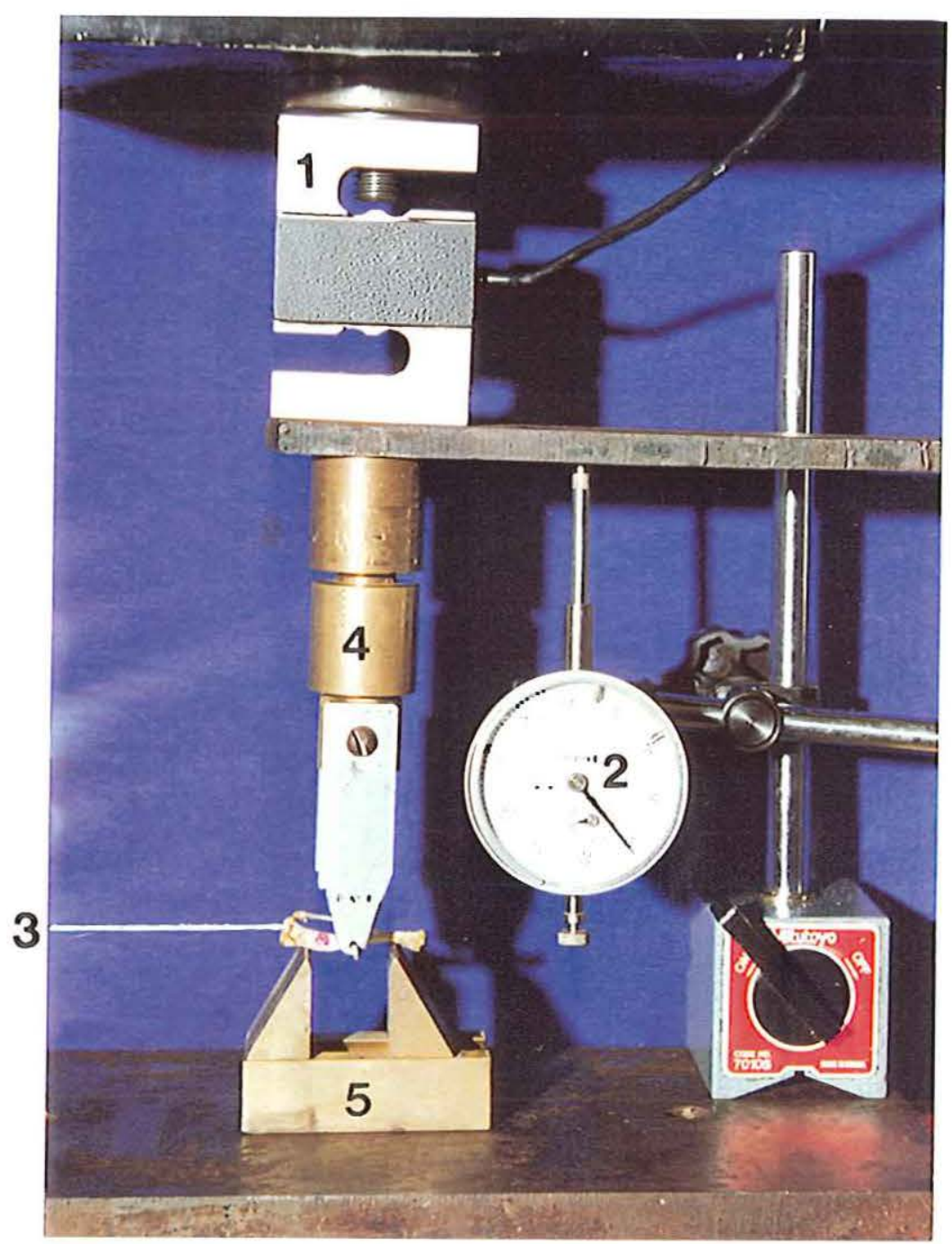

FIGURA 15. Montagem do ensaio de Flexão em tíbia e fibula de rato. 1- Célula de carga, 2- Relógio comparador, 3- Complexo tíbio-fibular, 4- Acessório para a aplicação da carga.

Foi aplicada uma pré-carga de 0,5 kgf, com tempo de acomodação de 1 minuto. Para cada ensaio a força foi aplicada perpendicularmente ao eixo maior da tíbia utilizando um fio de Kirschner colocado na face posterior da tíbia, aplicando esforços ao osso até a ruptura. Durante o período de ensaio os ossos também foram mantidos hidratados com soro fisiológico. Todos os ensaios foram realizados nas mesmas condições, com a tíbia sempre posicionada com a face anterior voltada para baixo logo, o ponto de aplicação da carga foi na face posterior da tíbia. 


\subsection{Obtenção dos Parâmetros Mecânicos}

Para cada ensaio, foi construído o gráfico carga $x$ deformação (compressão) e carga $x$ deflexão (flexão), e a partir da curva, obtidos os seguintes parâmetros mecânicos: carga máxima, deformação máxima e rigidez.

\section{7 Análise Estatística}

Todos os parâmetros definidos anteriormente foram analisados para o grupo com fibula e sem fibula. Foi realizada a análise comparativa entre esses dois grupos, utilizando o teste "t" de Student para variâncias equivalentes. O nível de significância dos testes foi de $5 \%$. Para isso foi utilizado um microcomputador com o programa Excel $7.0^{\circledR}$. 


\section{Resultados}

Dentre os vinte modelos de unidades tíbio-fibulares testados em compressão, foi observado que, em dezoito, as fraturas estavam localizadas na região epifisária da tíbia. A fratura mais freqüentemente observada foi do tipo incompleta oblíqua. Não houve, nestes casos, fratura da fibula. Foi observado apenas, o cisalhamento da cabeça da fibula com aumento de seu arqueamento, sem que houvesse, na maioria dos casos, separação da articulação tíbio-fibular.

Em apenas dois pares, houve fratura da tíbia e da fibula, ambas na região diafisária. A fratura observada nesses dois casos foi do tipo transversal completa. As curvas carga $x$ deformação de todos os ensaios com e sem fibula estão apresentados nas FIGURAS 16 e 17.

Em dezoito dos vinte pares de unidades tíbio-fibulares ensaiados em flexão, a fratura da tíbia estava localizada na região diafisária e foi do tipo transversal incompleta linear. Em um dos lados dos outros dois pares, a fratura também localizada na região diafisária, foi do tipo oblíqua incompleta. A envergadura da fibula aumentou durante a flexão, contudo, não chegou a ocorrer fratura da fibula, nem tão pouco houve separação da cabeça da fibula, como em dois casos no ensaio de compressão.

Dos vinte pares de unidades tíbio-fibulares testados em compressão, três foram desprezados e dos vinte pares testados em flexão, os desprezados foram seis. Em 1 caso houve escorregamento da peça durante o ensaio de flexão, e nos outros casos tanto no ensaio de compressão como no ensaio de flexão, a curva carga $x$ deformação foi irregular, diferenciando-se muito do padrão da curva dos outros ensaios FIGURAS 18 e 19. 


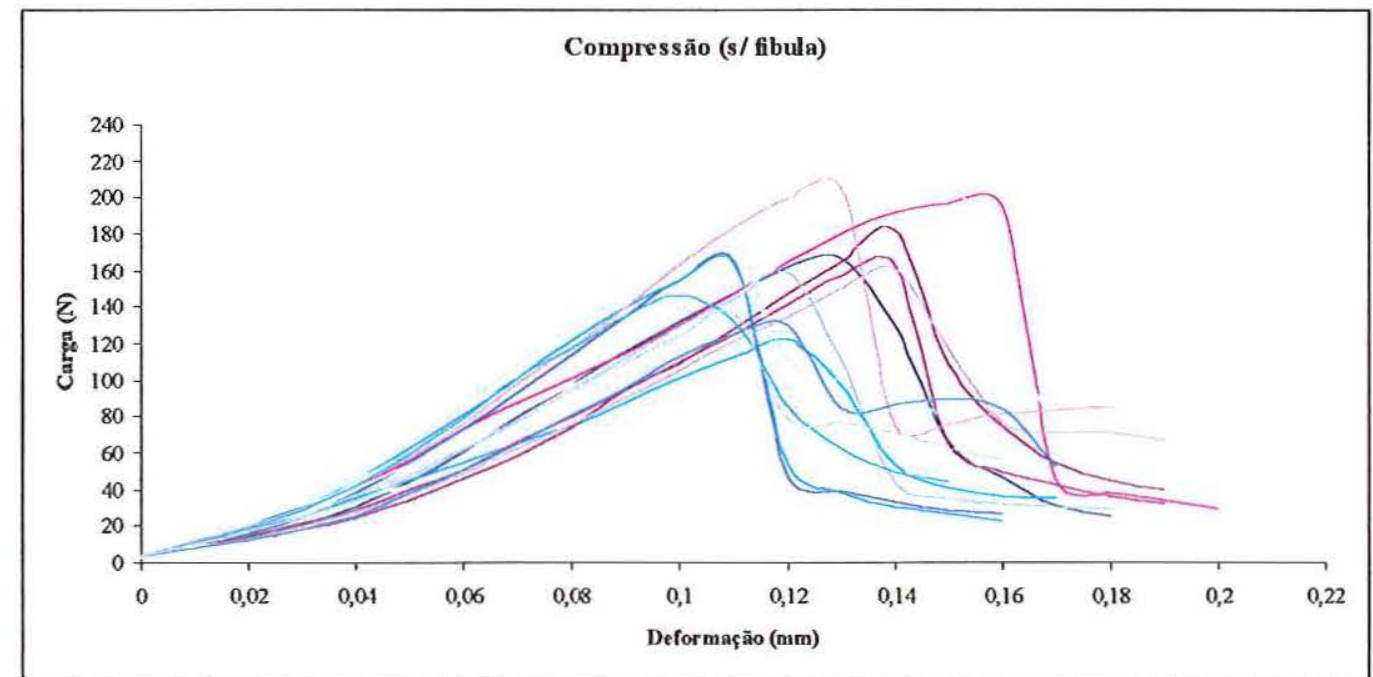

FIGURA 16. Curva carga $x$ deformação das tíbias ensaiadas com fibula em compressão.

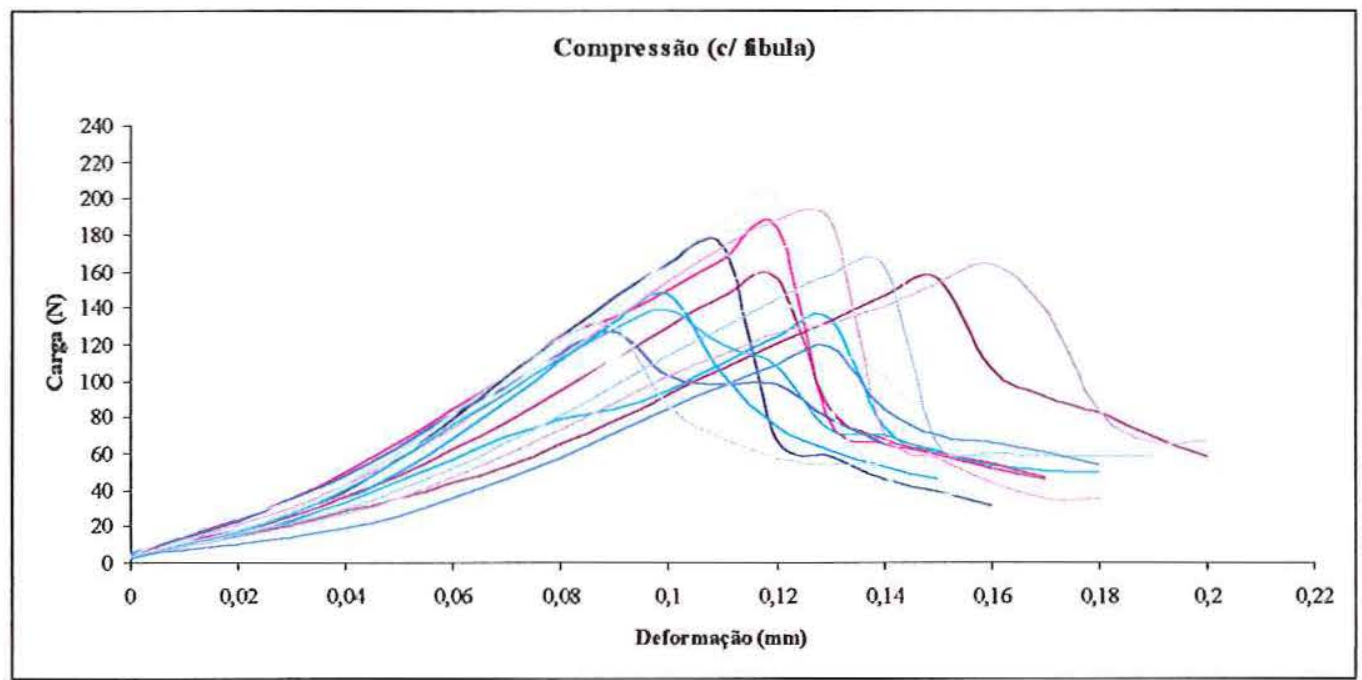

FIGURA 17. Curva carga $x$ deformação das tíbias ensaiadas sem fibula em compressão. 


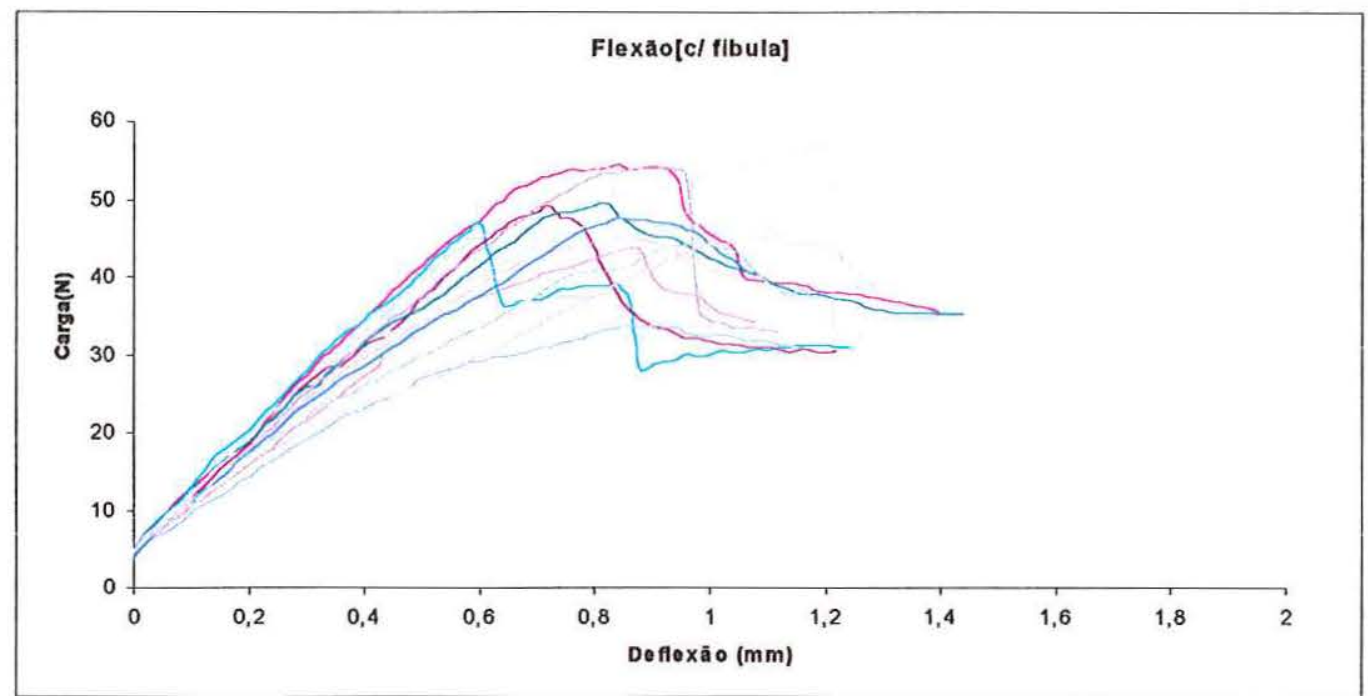

FIGURA 18. Curva carga $x$ deformação das tíbias ensaiadas com fibula em flexão

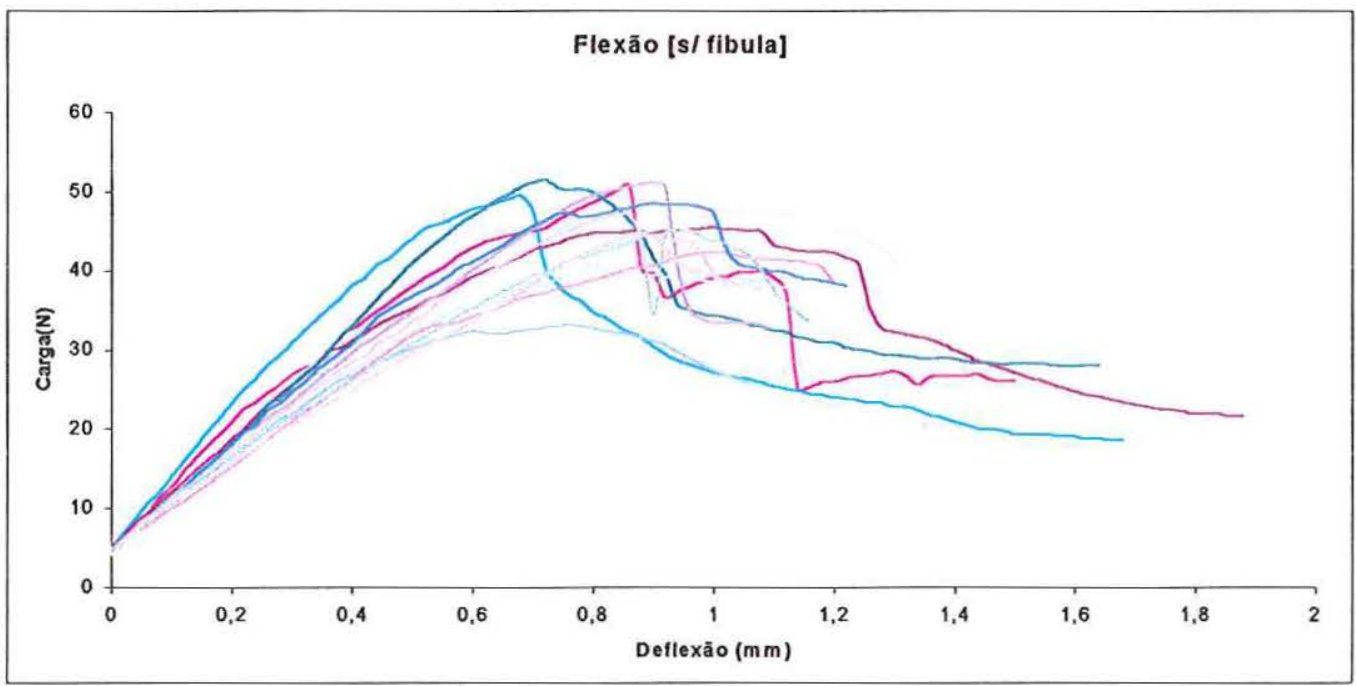

FIGURA 19. Curva carga $x$ deflexão das tíbias ensaiadas sem fibula em flexão

As médias aritméticas e desvio padrão da carga máxima, deformação máxima e rigidez obtidas nos ensaios de compressão e flexão em três pontos são mostrados na TABELA 1 . 
TABELA 1 Tabela das médias aritméticas e desvio padrão da carga máxima, deformação máxima e rigidez.

\begin{tabular}{lcccc}
\hline & \multicolumn{2}{c}{ flexão } & \multicolumn{2}{c}{ compressão } \\
\hline & c/ fíbula & s/ fíbula & c/ fíbula & s/ fíbula \\
\hline Carga máx. (N) & $47,80 \pm 5,72$ & $46,13 \pm 4,92$ & $157,47 \pm 27,11$ & $160,78 \pm 31,31$ \\
Deformação máx. $\left(\times 10^{-3} \mathrm{~m}\right)$ & $0,90 \pm 0,15$ & $0,91 \pm 0,12$ & $0,16 \pm 0,22$ & $0,13 \pm 0,15$ \\
Rigidez (x10 $\left.0^{+3} \mathrm{~N} / \mathrm{m}\right)$ & $58,32 \pm 9,87$ & $56,98 \pm 8,21$ & $1302,46 \pm 301,41$ & $1253,57 \pm 274,09$ \\
\hline
\end{tabular}

\subsection{Ensaio de flexão em três pontos}

\subsubsection{Carga máxima}

No ensaio de flexão, a média da carga máxima para as tíbias com fíbula integra foi $(47,80 \pm 5,72) \mathrm{N}$ e para as tíbias sem fibula foi $(46,13 \pm 5,17) \mathrm{N}$ (FIGURA 20). Não houve diferença significativa entre os dois valores de carga máxima $(\mathrm{p}<0,05)$.

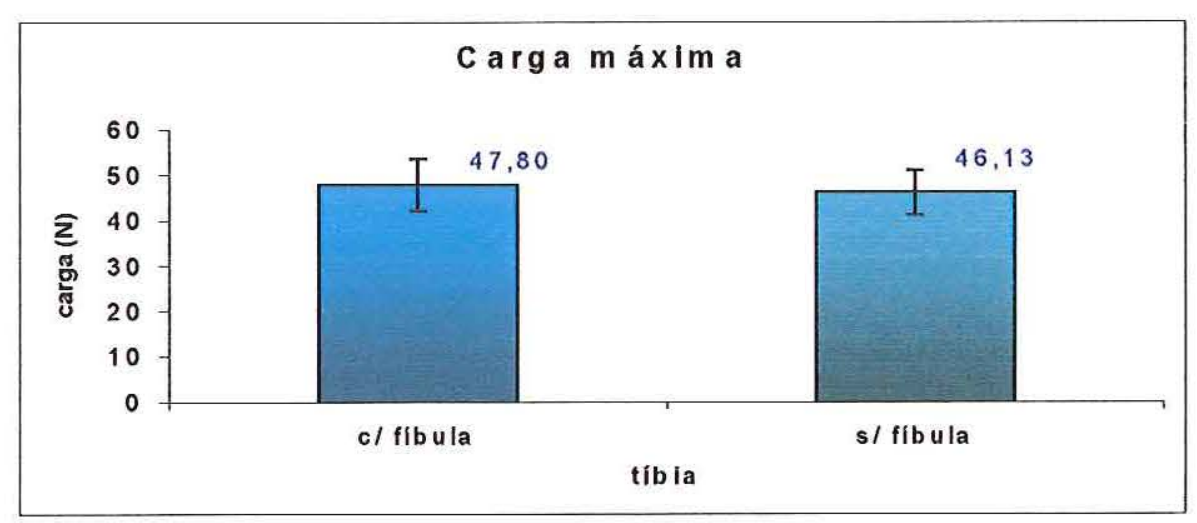

FIGURA 20. Médias aritméticas das cargas máximas para as tíbias ensaiadas em flexão. 


\subsubsection{Deformação máxima}

No ensaio de flexão, a média da deformação máxima para as tíbias com fíbula integra foi $(0,90 \pm 0,15) \times 10^{-3} \mathrm{~m}$ e para as tíbias sem fibula foi $(0,91 \pm 0,12) \times 10^{-3}$ $m$ (FIGURA 21). Não houve diferença significativa entre os dois valores de deformação máxima $(\mathrm{p}<0,05)$.

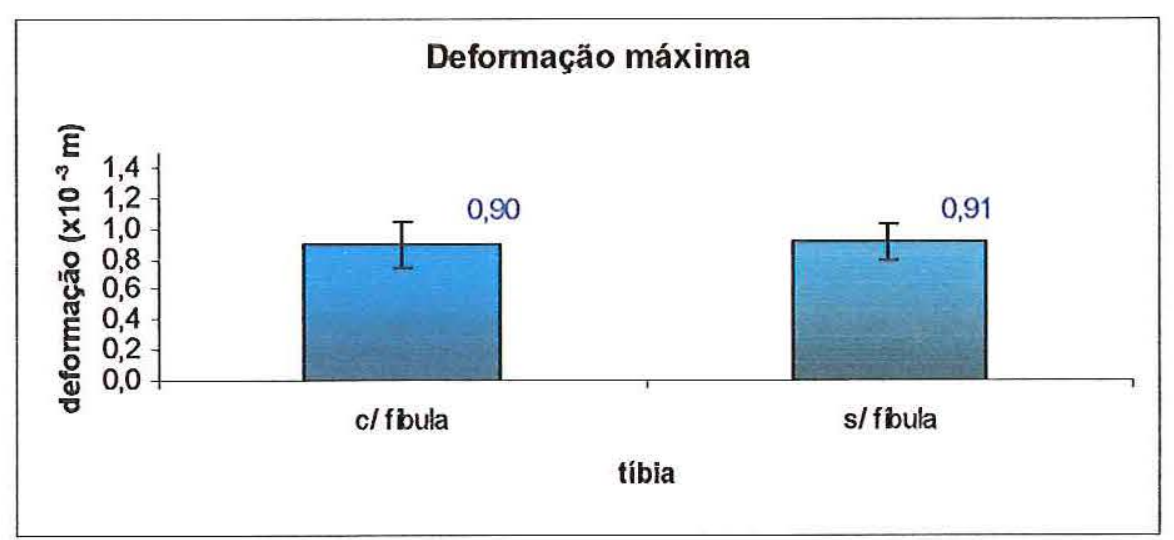

FIGURA 21. Médias aritméticas das deformações máximas para as tíbias ensaiadas em flexão.

\subsubsection{Rigidez}

No ensaio de flexão, a média da rigidez para as tíbias com fibula integra foi $(58,32 \pm 9,87) \times 10^{3} \mathrm{~N} / \mathrm{m}$ para as tíbias sem fibula foi $(56,98 \pm 8,21) \times 10^{3} \mathrm{~N} / \mathrm{m}$ (FIGURA 22). Não houve diferença significativa entre os dois valores de deformação máxima $(\mathrm{p}<0,05)$.

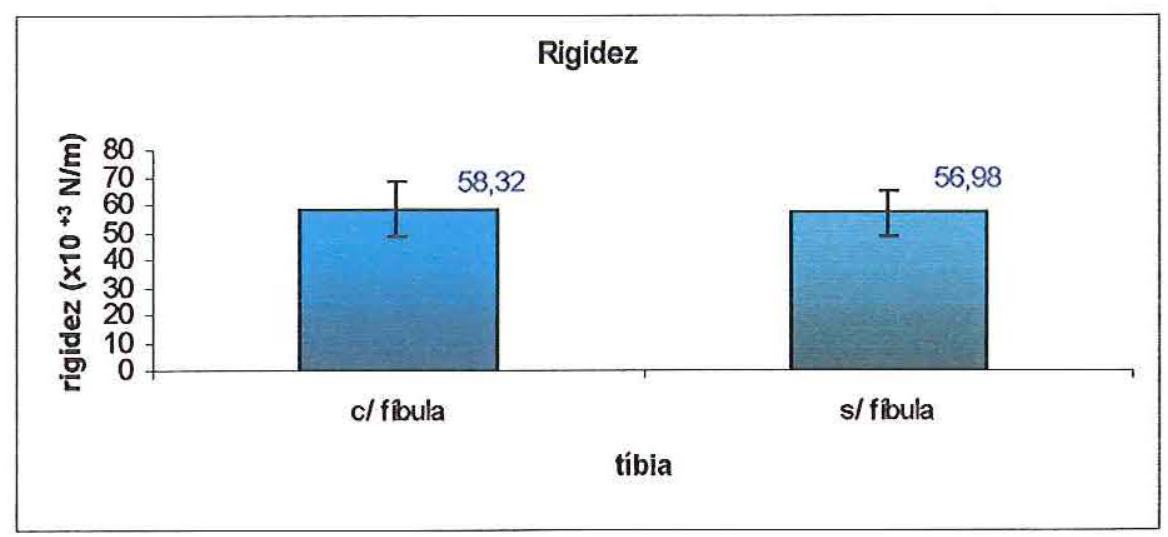

Figura 22. Médias aritméticas das rigidez para as tíbias ensaiadas em flexão. 


\subsection{Ensaio de Compressão}

\subsubsection{Carga máxima}

No ensaio de compressão, a média da carga máxima para as tíbias com fíbula integra foi $(157,47 \pm 27,11) \mathrm{N}$ e para as tíbias sem fíbula foi $(160,78 \pm 31,31) \mathrm{N}$ (FIGURA 23). Não houve diferença significativa entre os dois valores de deformação máxima $(\mathrm{p}<0,05)$.

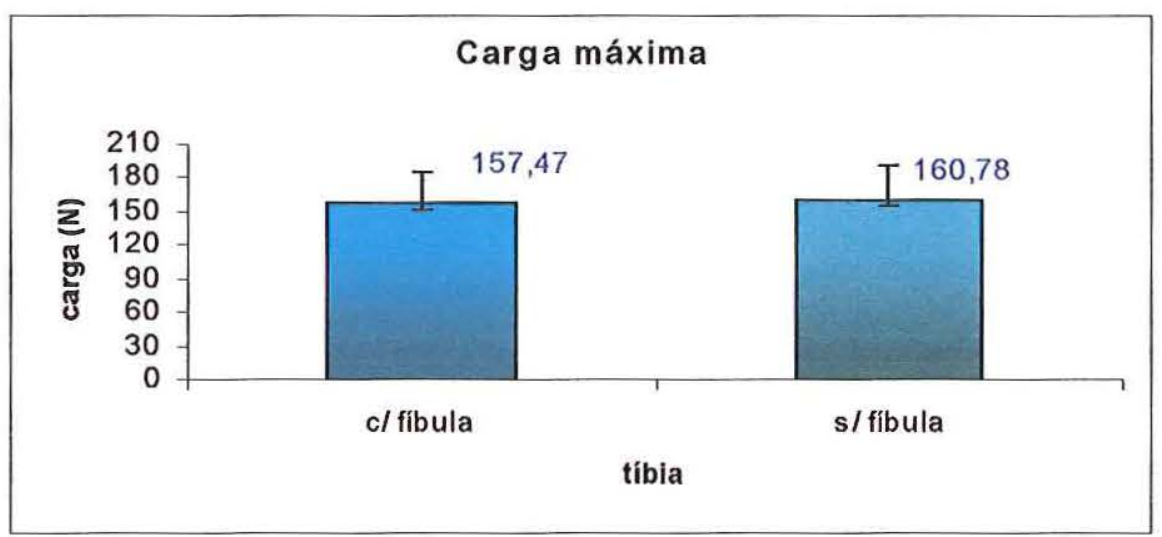

FIGURA 23. Médias aritméticas das cargas máximas para as tíbias ensaiadas em compressão.

\subsubsection{Deformação máxima}

No ensaio de compressão, a média da deformação máxima para as tíbias com fíbula integra foi $(0,16 \pm 0,02) \times 10^{-3} \mathrm{~m}$ e para as tíbias sem fíbula foi $(0,13 \pm 0,02)$ $\mathrm{x} 10^{-3} \mathrm{~m}$ (FIGURA 24). Não houve diferença significativa entre os dois valores de deformação máxima $(\mathrm{p}<0,05)$.

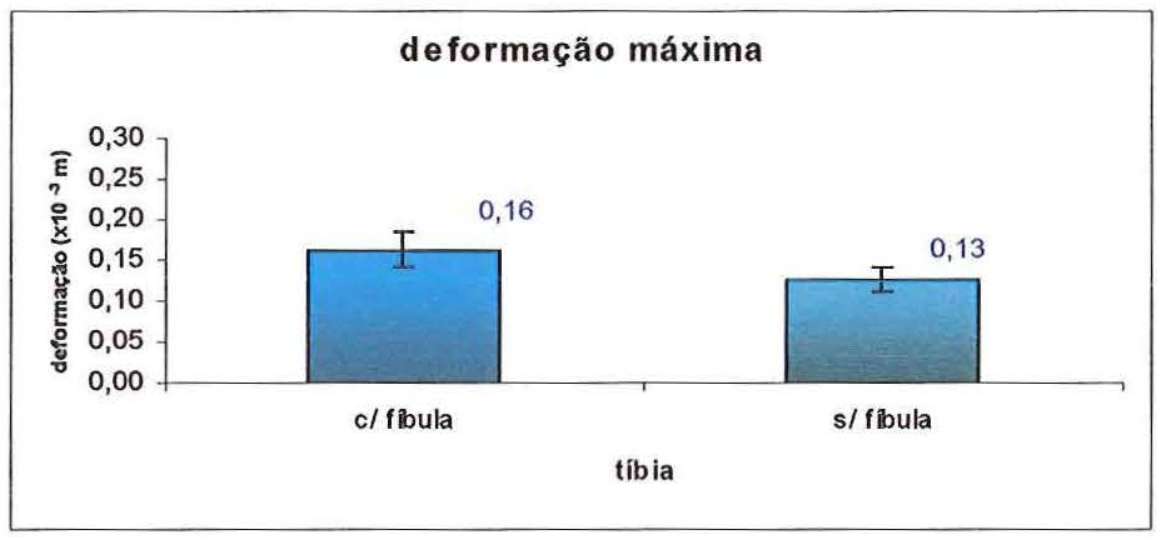

FIGURA 24. Médias aritméticas das deformações máximas para as tíbias ensaiadas em compressão. 


\subsubsection{Rigidez}

No ensaio de compressão, a média da rigidez para as tíbias com fíbula integra foi $(1302,46 \pm 301,41) \times 10^{3} \mathrm{~N} / \mathrm{m}$ e para as tíbias sem fíbula foi $(1253,57 \pm 274,09) \times 10^{3} \mathrm{~N} / \mathrm{m}$ (FIGURA 25). Não houve diferença significativa entre

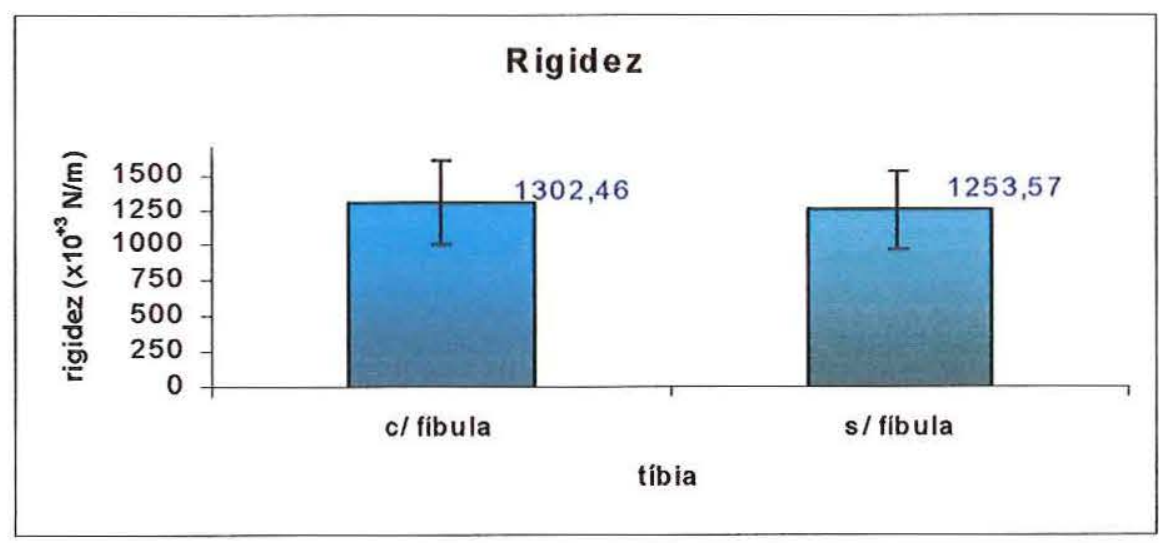

os dois valores de deformação máxima $(\mathrm{p}<0,05)$.

FIGURA 25. Médias aritméticas das rigidez para as tíbias ensaiadas em compressão. 


\section{DISCUSSÃO}

Entre os pesquisadores que investigam a ontogenia e a filogenia esquelética há, freqüentemente, opiniões de que existe codificação no genoma das células de origem esquelética com material de auto-instrução para regular intrinsecamente o processo responsável pela formação, maturação e crescimento (linearmente, volumetricamente e espacialmente ) dos elementos esqueléticos, como por exemplo, informação para seqüência particular do modelo específico do membro necessário (RUBIN \& SAUNDERS, 1972).

DE BEER apud MOSS (1977) ${ }^{20}$ procurou explicar que os fatores internos herdados de ancestrais, não são suficientes para determinar o desenvolvimento de um animal. Está claro, segundo esse autor, que, em todo o caminho do pleno desenvolvimento, os fatores internos não produzem nada por si mesmos, mas apenas capacitam o animal para reagir de maneira definitiva aos fatores externos adaptando-se ao surgimento de cada nova estrutura no processo de desenvolvimento.

Nos últimos anos, dados de várias fontes têm sugerido incisivamente que a morfologia dos elementos esqueléticos não são a expressão de regulação genômica ativa direta e primariamente codificadas nas próprias células formadoras do esqueleto (SAWIN \& HAMLET, 1972). Anteriormente, o que se considerava ser defeito genético específico, é agora entendido como uma resposta mecanicamente obrigatória dos tecidos esqueléticos mediante alterações prévias de estruturas não ósseas especificamente relacionadas (GRUNEBERG \& WICKRAMARATNE, 1974).

MOSS (1972) sugeriu que a interpretação desses conceitos apóia a suspeita de que as fusões dos elementos esqueléticos de membros não são eventos genomicamente codificados e auto-programados previamente no interior dos tecidos esqueléticos. Antes, estas fusões refletem de modo temporário e funcional antecedentes extrínsecos de eventos biomecânicos que ocorrem especificamente relacionados com tecidos não esqueléticos.

\footnotetext{
${ }^{20}$ DE BEER, G.R. (1962). Embryos and ancestrors . $3^{\text {rd }}$. Ed. Corrected. (Oxford University Press).
} 
Os dados presentes de fusões ósseas de membros inferiores, reforçam a hipótese de que fatores extrínsecos e não intrínsecos, são morfogeneticamente primários no esqueleto pós-cranial (MOSS,1972).

MOSS (1977), conforme descrito anteriormente, inibiu a fusão tíbio-fibular no rato após retirada da musculatura superficial (solear, gêmeos e plantar), sugerindo a relação direta entre a ação muscular e a ocorrência da fusão. Em um trabalho paralelo, este mesmo autor, ao analisar histologicamente a região onde ocorre a fusão tíbio-fibular do rato afirmou que é um local com tendência a sofrer esforços longitudinais. Sugeriu que a produção de cartilagem secundária que ocorre após contato distal entre a fibula e a tíbia é provocada extrinsecamente por ação dos músculos especificamente relacionados, tríceps sural e plantar (músculos considerados superficiais). Isso ocorre, segundo MOSS, por adaptação biomecânica ligada à funcionalidade do membro.

Uma série de estudos in vitro mostrou que o desenvolvimento das células ósseas e cartilaginosas pode ser influenciado por fatores extrínsecos existentes no meio ambiente (ASTRAND \& RODAHL, 1980). BASSET (1962) demonstrou que com a introdução de uma alta pressão de oxigênio a partir de uma cultura de tecido de fibroblastos primitivos, além da compactação da cultura, resultava em formação óssea. Com uma baixa oxigenação, resultava cartilagem.

WALMSLEY apud MOSS (1977) ${ }^{21}$ verificou que, em alguns animais, havia uma correlação entre a morfologia do tálus e sua relação com a tíbia e fibula na ocorrência ou não da fusão tíbio-fibular distalmente sugerindo, também, que a presença da fusão indicava uma adaptação estrutural por necessidade mecânica.

Uma relação entre ação muscular e adaptação estrutural foi proposta por CARLETON (1941) e por BARNETT \& NAPIER (1953), sugerindo a importância da ação muscular no processo de fusão tíbio-fibular do rato.

É interessante notar que MOSS (1977), ao descrever a sequência de eventos que antecedem a fusão tíbio-fibular em ratos e camondongos, relatou que a inclinação da extremidade proximal da tíbia, juntamente com o arqueamento medial

\footnotetext{
${ }^{21}$ WALMSLEY, T. (1918). The reduction of the mammalian fibula. J. anat. v.52, p. 327 - 331.
} 
do eixo da fibula, ocorreu anteriormente ao $4^{\circ}$ dia pós-natal. Portanto, sem que houvesse, até então, aplicação de forças tangenciais sobre a fibula, o que aconteceu apenas ulteriormente, provocado pelo contato das córtex de ambos os ossos, com produção de cartilagem secundária e subseqüente ossificação, levando à fusão das duas córtex. Esse fato indica uma provável ação dos tecidos não esqueléticos exercendo tensão sobre a fibula.

Previamente, foi sugerido que músculos do membro agindo por suas fixações periosteais, regulam a diferença de taxa específica do crescimento longitudinal, observado nas placas de crescimento dos ossos longos (MOSS, 1972).

Embora o atual conhecimento da genética molecular tenha esclarecido muitos dos mecanismos e processos de atividade genômica, esses mesmos dados não têm, ainda, preenchido o espaço entre eles próprios e os outros dados concernentes à estrutura e modelo do sistema esquelético (MOSS, 1977). Com vários trabalhos, MOSS et al., em 1971, procuraram demonstrar morfogeneticamente que a funcionalidade estabelece relação entre elementos esqueléticos e tecidos não esqueléticos (MOSS et. al., 1971; MOSS, 1972). Adicionando a isso, após seus experimentos, em 1977, MOSS declarou que as fusões pós-natal da tíbia com a fibula de roedores, são uma resposta de forças biomecânicas geradas por atividade cinética de músculos relacionados e conecções articulares específicas. A produção de cartilagem secundária no local da fusão, como demonstrou esse autor, é provocada por forças extrínsecas.

Segundo GETTY (1980), o fato de que um animal esforça-se para sobreviver em seu ambiente natural, dependendo de adaptações às exigências apresentadas pelo "habitat", algumas de natureza mecânica, deixa claro que as adaptações morfológicas resultantes das exigências de origem mecânica sobre o animal estabelecem os parâmetros para uma interpretação mecânica de sua estrutura.

Torna-se evidente que muitas perturbações e afeç̧ões traumáticas, e sua terapia no sistema locomotor, têm base mecânica. Portanto, um conhecimento básico dos processos mecânicos no animal vivo é de grande importância não apenas para o estudante e o médico veterinário (GETTY, 1980), mas também para os profissionais da saúde como médicos, fisioterapeutas, terapeutas ocupacionais, bem como para 
educadores fisicos, já que uma abordagem semelhante pode ser aplicada ao ser humano.

No caso do osso, isso se aplica em situações como a ocorrência de fraturas, bem como diante da necessidade de repará-las, seja com fixações internas ou externas. Os processos de desgaste articular de origem mecânica, ou mesmo diante da substituição de uma articulação por prótese, da mesma forma, requerem uma abordagem biomecânica.

Os mecanismos de lesão dos tecidos moles (músculos, tendões, ligamentos), tratamento dessas lesões e sua prevenção, são melhor entendidos, também sob o ponto de vista da biomecânica.

O movimento é a característica fundamental do corpo humano. Para consegui-lo o sistema locomotor (músculo-esquelético e articular) por meio de contrações musculares utiliza sistemas de alavancas e polias, formados pelos ossos, tendões e ligamentos (LEHMKUHL \& SMITH, 1987).

Para o fisioterapeuta, o conhecimento de príncipios da biomecânica é essencial, para a compreensão e manipulação das forças que agem sobre o corpo humano e que influenciam o movimento (gravidade, tônus muscular, resistência externa, atrito), na perspectiva de melhorar a ação humana e prevenir lesões. "Logo, quanto mais se compreendem as características e princípios básicos de operação dos sistemas que suportam e mantêm o comportamento do aparelho motor (sistema músculo-esquelético e articular), mais efetivo se pode ser na avaliação dos comprometimentos da função motora e na sugestão de soluções possíveis para os problemas clínicos" (LEHMKUHL \& SMITH, 1987).

Diante do objetivo deste estudo, que foi de investigar se a fibula, após fusão com a tíbia distalmente, contribuiria para aumentar a resistência da tíbia, procurou-se avaliar o comportamento mecânico da tíbia por meio da medida de algumas de suas propriedades mecânicas, submetendo-a aos esforços de compressão axial e flexão em três pontos, com e sem a presença da fibula, e comparando os dados obtidos nas diferentes situações. Foram medidas as seguintes propriedades mecânicas da tíbia e do complexo tibio-fibular: limite máximo (maior valor da carga suportada pelo material com a deformação correspondente), rigidez (grau de dureza do osso). 
Caracterizando o osso por meio da curva carga $x$ deformação (compressão) e carga $x$ deflexão (flexão).

Ao se examinar a estrutura óssea sob a óptica da Mecânica, há certa dificuldade uma vez que suas leis são descritas para corpos rígidos que possuem uniformidade estrutural. Como o osso é anisotrópico, ocorre uma variação das propriedades ósseas de diferentes amostras com mesmas propriedades geométricas, devido à variação microestrutural introduzindo, assim, mais uma variável nas propriedades mecânicas.

Segundo COWIN (1989), embora teoricamente os ensaios mecânicos sejam confiáveis, os resultados obtidos podem ser afetados de muitas maneiras. Apesar de existirem normas para ensaiar os materiais normalmente usados em engenharia, tais normas não são fáceis de serem aplicadas ao osso, especialmente devido ao tamanho dos corpos de prova, o que é um fator limitante.

Em nosso estudo os animais selecionados eram adultos jovens pelo fato de apresentarem um tamanho razoável das tíbias e fibulas, facilitando a manipulação e fixação das amostras, para melhor visualização dos eventos ocorridos durante os ensaios e especialmente pelo fato da fusão tíbio-fibular distal no rato, ocorrer apenas após o sétimo dia de vida (MOSS, 1977).

O rato (Rattus Norvergicus albinus) foi escolhido pela facilidade de mantê-lo em laboratório, ser de baixo custo, apresentar crescimento bastante regular " e por dispormos de linhagem relativamente pura. Além disso, FONTOURA FILHO (1995) demonstrou, com estudo de tíbias de ratos, que os membros posteriores apresentam pouca variação morfológica em relação ao tamanho do rato adulto. Portanto, animais maiores e mais pesados apresentam pouca variação morfológica.

Devido sua grande importância na sustentação e movimentação do corpo humano, os ossos longos têm sido mais extensivamente estudados que outros ossos.

A utilização de ossos inteiros, neste estudo, justifica-se pelo interesse nas propriedades mecânicas do osso não como material, mas como estrutura intacta que, conforme os relatos de HAYES \& CARTER (1971), refletem melhor a capacidade mecânica.

A escolha de ensaiar a tíbia em compressão axial deve-se ao fato de que "in vivo" esse osso, assim como o fềmur, está orientado verticalmente, devido ao seu 
papel de sustentação do corpo, sofrendo, portanto, aplicação de carga no sentido longitudinal.

Já o ensaio de flexão, foi escolhido especialmente pela tendência da tíbia à flexão ( caracterizada por sua morfologia arqueada).

Nos ensaios de compressão, uma dificuldade normalmente encontrada é a fixação e o alinhamento das amostras no momento da aplicação do esforço. Uma vez que o osso não tem morfologia regular, para minimizar esse problema as tíbias foram fixadas resina acrílica.

A padronização metodológica do alinhamento foi facilitada pela fixação e ensaio em série das amostras, sendo que houve tempo para seguir a padronização com relação aos pontos de referência adotados no suporte em que cada amostra foi individualmente fixada durante a preparação dos modelos de prova. Entretanto, as fixações, de um modo geral, implicam em uma provável interferência nas medidas de deformação dos ossos, o que dificulta a obtenção da deformação real das amostras (PESSAN, 1996).

Outra questão relacionada com os ensaios compressivos, é quanto às medidas da amostra a ser ensaiada, cujo comprimento não deve ser maior do que duas vezes e meia o valor do seu diâmetro, para que não haja risco de flambagem (combinação de compressão e flexão). Nos ensaios de compressão, entretanto, não foi possível seguir essa norma uma vez que a região da fusão entre a tíbia e a fibula, assim " como a extremidade proximal da tíbia e da fibula precisaram ficar fora da região de inclusão em resina para que pudéssemos observar o comportamento dessa região durante o ensaio. Contudo, a medida da região não incluída em resina foi padronizada (28 $\mathrm{mm})$.

O ensaio de flexão em três pontos, traz a vantagem de ser simples, dispensa a utilização de fixadores para prender a amostra, que apenas repousa sobre os suportes e, além disso, a deformação é maior que em outros ensaios, o que facilita a tomada das medidas (SINKIN \& ROBIN, 1973).

Embora alguns pesquisadores critiquem o ensaio de flexão sugerindo que o atrito entre a amostra e os suportes provoque o aparecimento de tensões de cisalhamento nesta região (COWIN, 1989), o ensaios realizados neste estudo, mostraram-se bastante confiáveis, pela regularidade das curvas. Procurando evitar 
um outro problema apontado no ensaio de flexão, na perspectiva de minimizar o atrito, a peça que fica em contato com a amostra ao se aplicar a carga possuía forma arredondada.

Nos ensaios de compressão a maioria das tíbias apresentaram fraturas na região epifisária proximal, o que demonstra que as fraturas foram reprodutíveis. Portanto, foi possível verificar que a padronização do alinhamento dos modelos de prova, nesses ensaios, foi conseguida.

O deslocamento da cabeça da fibula demonstrou que ela sofreu cisalhamento. No animal (in vivo) essa força de cisalhamento provavelmente é minimizada pelos tecidos periarticulares (cápsula articular e ligamentos tíbio-fibulares) e pelos vários músculos inseridos na fibula proximalmente, especialmente pelo músculo solear, cujo tendão possui inserção na cabeça da fibula. Em nosso estudo esses músculos foram removidos.

As fraturas se localizaram na região em que o osso possui menor rigidez (osso trabecular), que é a parte mais deformável do osso.

$\mathrm{O}$ fato da maioria das fraturas da tíbia nos ensaios de flexão ter sido do tipo transversal, incompleta, linear e localizada na região diafisária, coincidindo com o ponto de aplicação da carga demonstra, também, a reprodutibilidade das fraturas, e confirma a padronização do sentido do carga aplicada.

As fraturas apenas da tíbia, em ambos os ensaios, sugerem que, embora em todos os casos tenha ocorrido aumento da envergadura da fibula, a força aplicada não ultrapassou o limite de ruptura da mesma ou ela não contribui para o aumento de resistência da tibia, aos esforços de compressão axial e flexão em três pontos. Isso sugere, entretanto, a capacidade da fibula de absorver energia mediante os dois tipos de carregamento.

A localização posterior da fibula em relação à tíbia, somada à flexão de sua diáfise, também posteriormente, aumenta a distância entre os eixos desses dois ossos, aumentando, assim, o ângulo de inserção do tendão do calcâneo, afastando-o do eixo longitudinal da tíbia. Essa disposição é importante para o músculo solear (uma vez que este músculo possui sua inserção proximal na cabeça da fibula e sua inserção distal no calcâneo através do tendão do calcâneo) e para outros músculos (plantares) menores, que se inserem também na fibula proximalmente. Esse fato aumenta o 
comprimento do braço de alavanca existente entre a tíbia e a fibula, gerando uma provável vantagem mecânica que melhora a eficiência muscular. Sendo assim, do ponto de vista dinâmico, o músculo solear precisa de menor força para gerar um torque no calcâneo, provocando sua rotação para efetuar flexão da articulação do tornozelo durante a locomoção, corrida ou saltitamento. Do ponto de vista estático, o solear precisaria realizar, também, menor esforço para desempenhar sua função excêntrica, antagonista à tendência de inclinação anterior da tíbia que favorece a flexão do joelho atuando, assim, com maior eficiência no equilíbrio postural.

A possibilidade de melhora da eficiência muscular parece ir de encontro às suspeitas de vários autores já citados, sugerindo que a fusão tíbio-fibular no rato, parece ser um mecanismo biomecânico de adaptação, específico dessa região para servirem aos propósitos funcionais do membro.

As alavancas mecânicas influenciam a força e a velocidade de contração muscular, assim como a amplitude de movimento articular (HALL, 1991). Esse tipo de alavanca observada nesta região do rato, é também encontrada no ser humano e fornece uma vantagem mecânica em relação à velocidade (LAPIERRE, 1980).

O entendimento dessa abordagem biomecânica é de importância para acelerar o processo de reabilitação de pacientes que necessitem de ganho de função e força muscular, o que se reflete na habilidade de realizar movimentos articulares mais harmônicos e mais amplos e eficientes acelerando, dessa forma, o processo de recuperação motora ou funcional de um indivíduo.

As afirmações feitas por MOSS (1977) sugerindo que a produção de cartilagem secundária com subseqüente fusão tíbio-fibular no rato ocorre por forças mecânicas geradas por atividade cinética dos músculos relacionados e coneç̧ões articulares específicas, sugerem a influência da ação muscular na consolidação de fraturas. Se os músculos especificamente relacionados com dois fragmentos ósseos, após a redução da fratura, forem estimulados a manter o tônus muscular (estado de tensão natural do músculo) durante o processo de consolidação óssea, com o objetivo de manter tensão constante entre os fragmentos (caso haja indicação) mediante contrações musculares isométricas (sem movimento articular), de grupos musculares agonistas e antagonistas (simultaneamente), é provável, que o reparo da fratura seja acelerado. 
Os resultados em nosso estudo concordam, portanto, com as suspeitas de MOSS (1977) que relaciona a fusão tibio-fibular distal no rato com necessidades funcionais de tecidos não esqueléticos para o desempenho das funções de um determinado membro. A fusão tíbio-fibular distal, portanto, não precisa, obrigatoriamente, aumentar a resistência da tíbia para suprir as necessidades mecânicas desta região.

É preciso atentar para o fato de que os dados obtidos em nosso estudo,mostrando que não houve diferença significativa entre as tíbias ensaiadas com e sem fibula, se aplica ao emprego de cargas estáticas. Avaliando, portanto, as unidades tíbio-fibulares em uma situação que acreditamos simular o papel de sustentação e absorção de forças realizado pela sistema esquelético. Sendo assim, não é possível extrapolar estes achados para uma situação dinâmica, como, quando o animal se locomove ou saltita, uma vez que existem inúmeras variáveis como por exemplo, o sentido, a natureza e a velocidade da aplicação de forças sobre o sistema músculo esquelético do animal, nessas situações.

Não foram realizados, neste estudo, ensaios de esforços torsionais. Ficando, portanto, como uma sugestão para futuros trabalhos.

Como já mencionado,não há na literatura consultada, estudos mecânicos envolvendo o complexo tibio-fibular do rato. Não houve, portanto, possibilidade de comparação dos resultados obtidos com este estudo.

Espera-se que os inúmeros beneficios trazidos pela caracterização das propriedades mecânicas do tecido ósseo, por meio dos ensaios mecânicos, despertem profissionais da área de reabilitação, bem como profissionais ligados à área desportiva, para a necessidade da mesma abordagem mecânica dos tecidos moles. 


\section{CONCLUSÃO}

Em ambos os ensaios (compressão axial e flexão em três pontos), não houve diferença significativa, sob o ponto de vista estático, de aumento de resistência das tíbias testadas com e sem fibula. Assim, a presença da fibula parece ser mais relacionada com função de inserções musculares do que fortalecimento do conjunto tibio-fibular. 


\section{REFERÊNCIAS BIBLIOGRÁFICAS}

ABRAM, A.C.; KELLER, T.S.; SPENGLER, D.M. (1988). The effects of simulated Weightlessness on bone and biochemical properties in the maturing rat. J. Biomech. USA, v.21, p.755-767.

ASTRAND, P.O.; HODAHL, K. (1980). Tratado de fisiologia do exercício. Rio de Janeiro. Editora Interamericana, $2^{\mathrm{a}}$ ed., p.246-252.

BARNETT, C.H.; NAPIER, J.R. (1953a). The rotary mobility of the fibula in eutherian mammals. J. Anat. v.87, p.11 - 21.

BARNETT, C.H.; NAPIER, J.R. $\left(1953^{b}\right)$. The form and mobility of the fibula in metatherian mammals. J. Anat. v.87, p.207 - 213.

BASSET, C.A.I. (1962). Current concepts of bone formation. J. Bone Joint Surg., v. $44^{\mathrm{A}}, \mathrm{p} .496$.

BEER, F.P.; JOHNSTON, R. Jr. (1981). Resistência dos materiais. 2 ' ed., Ed. McGraw-Hill, p.181.

BEER,F.P.JOHNSTON Jr,. E. R. (1992). Mechanics of Materials. McGraw-Hill.

CARLETON, A. (1941). A comparative study of the inferior tibia-fibula joint. J. Anat., v.76, p.45-55.

CARTER, D.R.; SPENGLER, D.M. (1978). Mechanical properties and composition of cortical bone. Clin. Orthop. USA, v.135, p.192 - 217.

CHIAVERINI, V. (1977). Tecnologia mecânica: estrutura e propriedades; processo de fabricação. São Paulo, Mc Graw-Hill do Brasil, p.86 - 96.

COWIN, S.C. (1989). The mechanical properties of cortical bone tissue. In: "Bone mechanics". Boca Raton, CRC Press, p.97 - 127.

CURREY, J.D.; BUTLER, A.G. (1975). The mechanical properties of bone tissue in children. J. Bone Joint Surg. USA, v. 57, p.810 - 814.

DEMPSTER, W.T.; LIDDICOAT, R.T. (1952). Compact bone as a non-isotropic material. Am. J. Anatomy, v.91, p.331 - 362.

DURKIN, J.F.; IRVING, J.T.; HEELEY, J.D. (1971). Observations of rat tibial articular cartilage during maturation. Archs Oral Biol, v.16, p.827 - 829.

ENNEKING, W. F. (1948). The repair of complete fractures of rat tibias. Anat. Rec. v. 101, p. $515-528$.

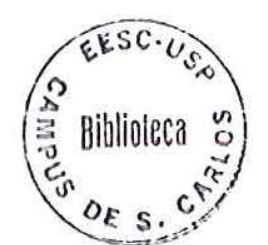


ENGESAETER, L.B.; EKELAND, A.; LANDELAND, N. (1978). Methods foretasting the mechanical properties of thereat femur. Acta Orthop Scand, v.49, p. $512-518$.

EINHORN, T.A. (1992). Bone strength: The bottom line. Calcif. Tissue Int. v.51, p.333- 339 .

EINHORN, T.A. (1996). Mechanical properties of bone. In "Principles of bone biology" (BILEZIKIAN, J. P.; RAISZ, L. G.; RODAN, A.G.) Academic Press, California USA, p.27 -37.

EVANS, F.G. (1982). Bone and ones. J. Biomech. Eng. v. 104, p. 1 - 5.

FILHO, F.C. (1995). Ensaio de cisalhamento na placa de crescimento proximal da tíbia da ratas em idades diferentes. Dissertação de mestrado. Universidade de São Paulo - F.M.R.P. p.25.

GETTY, R. (1980). Anatomia dos animais domésticos. Editora Interamericana. Rio de Janeiro, $5^{\circ}$ ed., p. 47.

GLUCKSMANN, A. (1939). Studies on bone mechanics in vitro. II. The role of tension and pressure in chondrogenesis. Anat. Rec. v. 73, p. 39- 55.

GOULD III, J.A. (1993). Fisioterapia na Ortopedia e na Medicina do Esporte. Editora Manole. São Paulo. 2 ed.. p.3.

GREENE, E.C. (1963). Anatomy of rat. Hafner Publishing Company. Academic Press. New York and London. v. XXVII, p. 58.

GRUNDNES, O.; REIKERAS, O. (1992). Effects of function on rat femora. Acta Orthop Scand, v.63, p.70 - 73.

GRUNEBERG, H.; WICKRAMARATNE, G. A. (1974). A re-examination of the skeletal mutants of the mouse, vestigial tail (vt) and congenital hydrocephalus (ch). J. Embryol. Exp. Morph. v. 31, p. 227 - 222.

HALL, B. K. (1970). Cellular differentiation in skeletal tissues. Biol. Rev. v. 45, p. $455-484$.

HALL, B. K. (1971). Calcification of the cartilage formed on aivan membrane bones. Clin. Orthop. v. 78, p. 182- 190.

HALL, B.K. (1972,a,b). Immobilization and cartilage transformation into bone in the embryonic chick. Anat. Rec. v. 173, p. 391 - 404.

HALL, B.D., JACOBSON, H.N. (1975). The repair of fractured membrane bones in the newly hatched chick. Anat. Rec., v.181, p.55-70. 
HALL, S.J. (1991). Biomecânica Básica. Rio de Janeiro S. A. Editora Guanabara Koogan. p.64.

HAYES, W.C. \& CARTER DR. Biomechanics of bone. In. Skeletal Research, SIMMONS, D.J. ; KUNIN, A.S. (ed). Academic Press, New York, v. 1, p.263 300 (1971).

HERT, J.; FIALA, P.; PETRTYL, M. (1994). Osteon orientation of the diaphysis of the long bones in man. Bone v. 15, p.269- 277.

HOYER, H.E.; LIPPERT, H. (1982). Biomechanics changes in long limb bones of Han-Wistar rats during postnatal development. Anatomy and Embryology, v. 164, p.101-111.

HORATH, L. (1995). Fundamental of Materials Science for Technologist-Properties, Testing, and Exercises Laboratories, New Jersey, Prentice Hall, p.333 - 337.

KELLER, T.S.; SPENGLER, D.M.; CARTER, D.R. (1986). Geometric, elastic, and structural properties of maturing rat femora. J. Orthop. Res. USA, v. 4, p.557 67.

LAPIERRE, A. (1980). Reeducação física. Editora Manole. São Paulo. 6 ' ed., v.1, p.29.

LEHMKUHL, L. D.; SMITH, L. (1987). Cinesiologia Clínica de BRUNNSTROM. São Paulo. Editora Manole. 4 ed., p. 1.

MARTER, B.S.; M.B.; F.R.C.S.; F.R.A.C.S.; N.H., M.R.C. (1967). Correlations between strength and other properties of long bones. J. Trauma USA, v. 7,'pp. $633-638$.

MARTER, B.S.; M.B.; F.R.C.S.; F.R.A.C.S.; N.H., M.R.C. (1967). He symmetry of the mechanical properties of the human femur. J. Surg. Res., v. 7, p. $222-225$.

McALISTER, G.B., MOYLE, D.D. (1983). Some Mechanical Properties of Goose Femoral Cortical Bone, J. biomechanics, v.16, p.577 - 589.

MINDEL, E. R.; RODBARD, S.; KWASMAN, B. G. (1971). Chondrogenesis in bone repair. Clin. Orthop. v. 79, p. 187 - 196.

MOSS, M. L. (1958). Fusion of the frontal suture in the rat. Am. J. Anat. v. 102, p. $119-142$.

MOSS, M. L.; MEEHAN, M., SALENTIJN, L. (1971). Transformative and translative growth processes in neurocranial development in the rat. Acta anat., v. 81, p. $161-182$. 
MOSS, M. L. (1972). A functional cranial analysis of primate cranio-facial growth. $4^{\text {th }}$ Int. Congr. on Primatology. v. 3, p. $191-208$.

MOSS, M. L. (1977). The functional analysis of fusion of tibia and fibula in the rat and mouse. Acta Anat. v. 97, p. $321-332$.

PESSAN, V. J. O. (1996). Ensaio de flexão em três pontos nas faces anterior e posterior de fềmures de rata, em duas fases diferentes de crescimento. Dissertação de mestrado. Universidade de São Paulo - F.M.R.P. p.42.

REILY, D.T.; BURSTEIN, A.H. (1974). The mechanical properties of cortical bone. J. Bone Joint Surg AS, v. 56, p.1001 - 1022.

RUBIN, L.; SAUNDERS, J.W., jr (1972). Ectodermal-mesodermal interaction in the growth of limb buds in the chick embryo: constancy and temporal limits of the ectodermal induction, Devel Bol., v. 28, p.94 - 112.

TURNER, C.H.; CHANDRAN, A.; PIDAPARTI., R.M. (1995). The anisotropy of osteonal bone and its ultrastructural implications. Bone v. 17, p.85 - 89.

TORZILLI, P.A.; TAKEBE, K.; BURSTEIN, A.H.; ZIKA, J.M.; HEIPLE, K.G. (1982). The material properties of immature bone. J. Biomech Eng USA, v.104, p.12- 20 .

SAWIN, P.B.; HAMLET, M. (1972). Morphogenetic studies of the rabbit. XIII. Growth gradients, epigenetic variants and function. Am. J. Anat., v.35, p. 105 118.

SCHAFFLER, M.B.; PITCHFORD, W.C., CHOI, K.; RIDDLE, J.M. (1994). Examination of compact bone microdamage sing back-scattered electron microscopy. Bone v. 15. p.483 - 488 .

SEDLIN, E. D.; HIRSCH, C. (1966). Factors affecting the determination of the physical properties of femoral cortical bone. Acta Orthop Scand, v.37, p. 29 - 48.

SHIMANO, A. C. (1994). Análise das propriedades geométricas e mecânicas d tíbia humana: Proposta de metodologia. Tese de doutorado. Universidade de São Paulo - E.E.S.C., Departamento de Engenharia Mecânica, p.8 - 9.

SIMKIN, A., ROBIN, G. (1973). The mechanical testing of bone in bending. J Biomech USA, v.6, p.631 - 639.

SOUZA, S.A. (1974). Ensaios mecânicos de materiais metálicos. São Paulo, Editora da Universidade de São Paulo, p.1 - 18.

STANITSKI, C.I.; McMASTER, J.H.; SERANTON, P.E. (1978). On the nature of stress fractures, Am. J. Sports Med. v.6, p.391 - 396. 
TIMOSHENKO, S.P. (1971). Resistência dos materiais. Rio de Janeiro, Editora da Universidade de São Paulo, v.1, p.23 - 30.

VOLPON, J. B. (1984). Apostila do curso regular de Medicina da Universidade de São Paulo, F.M.R.P., p.1 - 2.

WEINERT, C.R.; McMASTER, J.H.; FERGUSON, R.J. (1973). Dynamic function of the human fibla. Am. J. Anat., v.138, p.145-150. 


\section{ANEXO I}

Quadros com os valores máximos de carga, deformação e rigidez nos ensaio de flexão e compressão e análise estatística. 
TABELA X. Valores máximos para Carga, Deformação e Rigidez .

\begin{tabular}{|r|r|r|r|r|r|r|r|}
\hline Compressäo & $\begin{array}{r}\text { Carga máx. } \\
\text { (c/ fibula) }\end{array}$ & $\begin{array}{c}\text { Carga máx. } \\
\text { (s/fibula) }\end{array}$ & $\begin{array}{r}\text { Def. máx. } \\
\text { (c/ fibula) }\end{array}$ & $\begin{array}{l}\text { Def. máx. } \\
\text { (s/ fibula) }\end{array}$ & $\begin{array}{r}\text { Rigld. máx. } \\
\text { (c/ fibula) }\end{array}$ & $\begin{array}{r}\text { Rigid.máx. } \\
\text { (s/ fibula) }\end{array}$ \\
\hline 1 & 172,75 & 166,28 & 0,11 & 0,13 & 2170,95 & 1696,15 \\
\hline 2 & 184,33 & 196,40 & 0,12 & 0,15 & 1859,00 & 1490,14 \\
\hline 3 & 161,67 & 125,18 & 0,14 & 0,12 & 1360,65 & 944,70 \\
\hline 4 & 133,42 & 121,94 & 0,13 & 0,12 & 1155,62 & 1000,62 \\
\hline 5 & 155,88 & 181,78 & 0,15 & 0,14 & 917,23 & 1221,35 \\
\hline 6 & 155,88 & 162,26 & 0,12 & 0,14 & 1458,75 & 1274,32 \\
\hline 8 & 126,75 & 164,91 & 0,09 & 0,11 & 1664,76 & 1903,14 \\
\hline 9 & 146,66 & 163,63 & 0,1 & 0,11 & 1907,06 & 1924,72 \\
\hline 10 & 200,32 & 173,44 & 0,12 & 0,11 & 1974,75 & 2063,04 \\
\hline 11 & 169,71 & 179,03 & 0,11 & 0,11 & 1776,59 & 1824,66 \\
\hline 12 & 200,52 & 219,74 & 0,14 & 0,14 & 1456,785 & 1404,79 \\
\hline 13 & 163,04 & 158,43 & 0,14 & 0,12 & 1291,977 & 1496,03 \\
\hline 14 & 187,86 & 205,03 & 0,16 & 0,13 & 1768,743 & 1913,93 \\
\hline 15 & 163,43 & 160,79 & 0,16 & 0,14 & 1160,52 & 1220,36 \\
\hline 17 & 118,21 & 129,98 & 0,13 & 0,12 & 980,019 & 1371,44 \\
\hline 18 & 138,62 & 146,46 & 0,1 & 0,1 & 1797,192 & 1918,84 \\
\hline 19 & 129,59 & 135,87 & & 0,9 & 0,11 & 2012,031 & 1441,09 \\
\hline
\end{tabular}

\begin{tabular}{|c|c|c|c|}
\hline \multicolumn{4}{|c|}{$\begin{array}{l}\text { Teste-t: duas amostras presumindo variânclas } \\
\text { equivalentes }\end{array}$} \\
\hline Carga Máx. & & & \\
\hline & c/flbula & s/flbula & \\
\hline Média & 159,332 & 164,1845 & \\
\hline Variância & 628,8459 & 753,3921 & \\
\hline Observações & 17 & 17 & \\
\hline $\begin{array}{l}\text { Variância } \\
\text { agrupada }\end{array}$ & 691,119 & & \\
\hline $\begin{array}{l}\text { Hipótese da } \\
\text { diferença de } \\
\text { média }\end{array}$ & 0 & & \\
\hline gl & 32 & & \\
\hline Stat t & $-0,538152$ & & \\
\hline $\begin{array}{l}P(T<=t) \text { uni- } \\
\text { caudal }\end{array}$ & 0,297098 & & \\
\hline $\begin{array}{l}\text { t crítico unl- } \\
\text { caudal }\end{array}$ & 1,93888 & & \\
\hline $\begin{array}{l}\mathrm{P}(\mathrm{T}<=\mathrm{t}) \text { bi- } \\
\text { caudal }\end{array}$ & 0,594196 & & \\
\hline $\begin{array}{l}\text { t crítico bi- } \\
\text { caudal }\end{array}$ & 2,036932 & & \\
\hline
\end{tabular}




\begin{tabular}{|c|c|c|c|}
\hline \multicolumn{4}{|c|}{$\begin{array}{l}\text { Teste-t: duas amostras presumindo variânclas } \\
\text { equivalentes }\end{array}$} \\
\hline \multicolumn{2}{|l|}{ Def. Máx. } & \multirow[b]{2}{*}{ s/ fibula } & \\
\hline & c/fibula & & \\
\hline Média & 0,17176471 & 0,12353 & \\
\hline Variância & 0,03564044 & 0,00021 & \\
\hline Observaçð̃es & 17 & 17 & \\
\hline $\begin{array}{l}\text { Variância } \\
\text { agrupada }\end{array}$ & 0,0179261 & & \\
\hline $\begin{array}{l}\text { Hipótese da } \\
\text { diferença de } \\
\text { média }\end{array}$ & 0 & & \\
\hline$g \mid$ & 32 & & \\
\hline Stat $t$ & 1,05034374 & & \\
\hline $\begin{array}{l}\mathrm{P}(\mathrm{T}<=\mathrm{t}) \text { uni- } \\
\text { caudal }\end{array}$ & 0,150714 & & \\
\hline $\begin{array}{l}\text { t critico uni- } \\
\text { caudal }\end{array}$ & 1,69388841 & & \\
\hline $\begin{array}{l}\mathrm{P}(\mathrm{T}<=\mathrm{t}) \mathrm{bi}- \\
\text { caudal }\end{array}$ & 0,30142801 & & \\
\hline $\begin{array}{l}\text { t critico bl- } \\
\text { caudal }\end{array}$ & 2,03693162 & & \\
\hline
\end{tabular}

\begin{tabular}{|c|c|c|c|}
\hline \multicolumn{4}{|c|}{$\begin{array}{l}\text { Teste-t: duas amostras presumindo varlânclas } \\
\text { equivalentes }\end{array}$} \\
\hline RIgldez & & & \\
\hline & c/fibula & s/flbula & \\
\hline Média & 1571,331 & 1535,842 & \\
\hline Variância & 145007,5 & 120151,1 & \\
\hline Observaçōes & 17 & 17 & \\
\hline $\begin{array}{l}\text { Variância } \\
\text { agrupada }\end{array}$ & 132579,3 & & \\
\hline $\begin{array}{l}\text { Hipótese da } \\
\text { diferença de } \\
\text { média }\end{array}$ & 0 & & \\
\hline gl & 32 & & \\
\hline Stat t & 0,284164 & & \\
\hline $\begin{array}{l}\mathrm{P}(\mathrm{T}<=\mathrm{t}) \text { uni- } \\
\text { caudal }\end{array}$ & 0,389058 & & \\
\hline $\begin{array}{l}\text { t crítico uni- } \\
\text { caudal }\end{array}$ & 1,693888 & & \\
\hline $\begin{array}{l}\mathrm{P}(\mathrm{T}<=\mathrm{t}) \text { bi- } \\
\text { caudal }\end{array}$ & 0,778115 & & \\
\hline $\begin{array}{l}\text { t crítico bi- } \\
\text { caudal }\end{array}$ & 2,036932 & & \\
\hline
\end{tabular}




\begin{tabular}{|r|r|r|r|r|r|r|r|r|}
\hline Flexäo & & $\begin{array}{r}\text { Carga máx. } \\
\text { (c/ flbula) }\end{array}$ & $\begin{array}{c}\text { Carga máx. } \\
\text { (s/fibula) }\end{array}$ & $\begin{array}{r}\text { Def. máx. } \\
\text { (c/ fibula) }\end{array}$ & $\begin{array}{l}\text { Def. máx. } \\
\text { (s/ fibula) }\end{array}$ & $\begin{array}{r}\text { Rigid. máx. } \\
\text { (c/ fibula) }\end{array}$ & $\begin{array}{l}\text { Rigid.máx. } \\
\text { (s/ fibula) }\end{array}$ \\
\hline 2 & & 54,24 & 50,61 & 0,84 & 0,88 & 71,8738 & 62,04198 \\
\hline 3 & 51,6 & 50,22 & 0,92 & 1,1 & 63,3056 & 56,48552 \\
\hline 4 & 46,79 & 49,34 & 0,6 & 0,68 & 69,00282 & 72,34629 \\
\hline 6 & 49,05 & 45,51 & 0,72 & 1 & 63,93741 & 57,34321 \\
\hline 7 & 49,54 & 50,52 & 0,82 & 0,74 & 59,20155 & 73,05231 \\
\hline 10 & 48,27 & 47,19 & 0,98 & 1,1 & 59,96976 & 52,68483 \\
\hline 11 & & 56,70 & 40,61 & 1,2 & 0,82 & 67,28416 & 50,95962 \\
\hline 13 & 33,65 & 33,16 & 0,92 & 0,78 & 42,13062 & 47,47647 \\
\hline 14 & 43,65 & 42,28 & 0,8 & 1 & 56,28365 & 52,17196 \\
\hline 15 & 54,05 & 51,01 & 0,92 & 0,92 & 65,54149 & 58,10379 \\
\hline 16 & & 45,03 & 47,09 & 0,88 & 0,86 & 56,73323 & 56,53135 \\
\hline 17 & 47,38 & 48,46 & 0,86 & 0,92 & 55,2961 & 62,22203 \\
\hline 19 & 44,73 & 45,13 & & 1 & 0,98 & 46,59695 & 49,36973 \\
\hline 20 & & 44,64 & 44,83 & & 1,14 & 0,9 & 39,33057 & 46,93414 \\
\hline
\end{tabular}

\begin{tabular}{|c|c|c|c|}
\hline \multicolumn{4}{|c|}{$\begin{array}{l}\text { Teste-t: duas amostras presumindo variâncias } \\
\text { equivalentes }\end{array}$} \\
\hline Carga Máx. & & & \\
\hline & c/ fíbula & s/fíbula & \\
\hline Média & 47,80873 & 46,1398 & \\
\hline Variância & 32,67801 & 24,1753 & \\
\hline Observaçōes & 14 & 14 & \\
\hline $\begin{array}{l}\text { Variância } \\
\text { agrupada }\end{array}$ & 28,42665 & & \\
\hline \begin{tabular}{|l|} 
Hipótese da \\
diferença de \\
média
\end{tabular} & 0 & & \\
\hline$\overline{g l}$ & 26 & & \\
\hline Stat t & 0,828168 & & \\
\hline $\begin{array}{l}\mathrm{P}(\mathrm{T}<=\mathrm{t}) \text { uni- } \\
\text { caudal }\end{array}$ & 0,207557 & & \\
\hline $\begin{array}{l}\text { t critico uni- } \\
\text { caudal }\end{array}$ & 1,705616 & & 7 \\
\hline $\begin{array}{l}P(T<=t) \text { bi- } \\
\text { caudal }\end{array}$ & 0,415113 & & \\
\hline $\begin{array}{l}\text { t crítico bi- } \\
\text { caudal }\end{array}$ & 2,055531 & & \\
\hline
\end{tabular}




\begin{tabular}{|c|c|c|c|}
\hline \multicolumn{4}{|c|}{$\begin{array}{l}\text { Teste-t: duas amostras presumindo variâncias } \\
\text { equivalentes }\end{array}$} \\
\hline \multicolumn{4}{|l|}{ Def. Máx. } \\
\hline & c/ fíbula & s/fibula & \\
\hline Média & 0,9 & 0,905714 & \\
\hline Variância & 0,023815 & 0,015657 & \\
\hline Observaçōes & 14 & 14 & \\
\hline $\begin{array}{l}\text { Variância } \\
\text { agrupada }\end{array}$ & 0,019736 & & \\
\hline $\begin{array}{l}\text { Hipótese da } \\
\text { diferença de } \\
\text { média }\end{array}$ & 0 & - & \\
\hline$\overline{g l}$ & 26 & & \\
\hline Stat t & $-0,107616$ & & \\
\hline $\begin{array}{l}\mathrm{P}(\mathrm{T}<=\mathrm{t}) \text { uni- } \\
\text { caudal }\end{array}$ & 0,457563 & & \\
\hline $\begin{array}{l}\text { t crítico uni- } \\
\text { caudal }\end{array}$ & 1,705616 & & \\
\hline $\begin{array}{l}\mathrm{P}(\mathrm{T}<=\mathrm{t}) \text { bi- } \\
\text { caudal }\end{array}$ & 0,915126 & & \\
\hline $\begin{array}{l}\text { t crítico bi- } \\
\text { caudal }\end{array}$ & 2,055531 & & \\
\hline
\end{tabular}

\begin{tabular}{|c|c|c|c|}
\hline \multicolumn{4}{|c|}{$\begin{array}{l}\text { Teste-t: duas amostras presumindo variâncias } \\
\text { equivalentes }\end{array}$} \\
\hline \multicolumn{4}{|c|}{\begin{tabular}{|r|l|l|} 
Rigidez & & \\
\end{tabular}} \\
\hline & Cl fibula & S/ fibula & \\
\hline Média & 58,3206 & 56,9802 & \\
\hline Variância & 97,3983 & 67,4114 & \\
\hline Observaçōes & 14 & 14 & \\
\hline $\begin{array}{l}\text { Variância } \\
\text { agrupada }\end{array}$ & 82,4048 & & \\
\hline $\begin{array}{l}\text { Hipótese da } \\
\text { diferença de } \\
\text { média }\end{array}$ & 0 & & \\
\hline gl & 26 & & \\
\hline Stat $t$ & 0,39064 & & \\
\hline $\begin{array}{l}P(T<=t) \text { uni- } \\
\text { caudal }\end{array}$ & 0,34962 & & \\
\hline $\begin{array}{l}\text { t crítico uni- } \\
\text { caudal }\end{array}$ & 1,70562 & & \\
\hline $\begin{array}{l}P(T<=t) \text { bi- } \\
\text { caudal }\end{array}$ & 0,69924 & & \\
\hline $\begin{array}{l}\text { t critico bi- } \\
\text { caudal }\end{array}$ & 2,05553 & & \\
\hline
\end{tabular}

